\author{
ACTA MYCOLOGICA \\ Vol. 46 (2): 137-178 \\ 2011
}

\title{
Rare species of Lepiota and related genera
}

\author{
BŁAŻEJ GIERCZYK ${ }^{1}$, ANNA KUJAWA ${ }^{2}$, ANDRZEJ SZCZEPKOWSKI ${ }^{3}$ \\ and PIOTR CHACHUŁA ${ }^{4}$
}

${ }^{1}$ Faculty of Chemistry, A. Mickiewicz University Grunwaldzka 6, PL-60-780 Poznań, hanuman@amu.edu.pl

${ }^{2}$ Institute for Agricultural and Forest Environment, Polish Academy of Sciences Field Station in Turew, Szkolna 4, PL-64-000 Kościan, ankujawa@man.poznan.pl

${ }^{3}$ Department of Mycology and Forest Phytopathology, Warsaw University of Life Sciences - SGGW

Nowoursynowska 159, PL-02-776 Warszawa, andrzej_szczepkowski@sggw.pl

${ }^{4}$ Pieniny National Park, Jagiellońska 107/3

PL-34-450 Krościenko n/Dunajcem, piotrekchacha@gmail.com

Gierczyk B., Kujawa A., Szczepkowski A., Chachuła P.: Rare species of Lepiota and related genera. Acta Mycol. 46 (2): 137-178, 2011.

The paper presents 47 fungi taxa (species and varietes) belonging to the genera Cystolepiota, Echinoderma, Lepiota, Leucoagaricus, Leucocoprinus, Macrolepiota and Melanophyllum, found in Poland, which have been not reported earlier from this area (18 species: Cystolepiota fumosifolia, C. moelleri, C. petasiformis, Echinoderma carinii, E. pseudoasperula, Lepiota angustispora, $L$. apatelia, L. cingulum, L. cortinarius var. audreae, L. cristata var. felinoides, $L$. forquignonii, L. rubella, Leucoagaricus cinerascens, L. ionidicolor, L. sericifer var. sericellatus, Macrolepiota heimii, M. rhodosperma var. rhodosperma, M. venenata) or have been known only from a few localities. For the species new to Poland short descriptions, based on the specimens examined and literature data, are given and their micromorphological characters are illustrated.

Key words: Basidiomycota, Agaricaceae, diversity, distribution, Poland 


\section{INTRODUCTION}

The genera Cystolepiota Singer, Echinoderma (Bon) Bon, Lepiota (Pers.) Grey, Leucoagaricus (Locq.) Singer, Leucocoprinus Pat., Macrolepiota Singer and Melanophyllum Velen. belong to the family Agaricaceae (Agaricomycetes, Basidiomycota; Kirk et al. 2008). Basidiocarps formed by those genera are collyboid or mycenoid, with free lamellae and distinct universal and partial veils. They are saprotrophic and grow mostly on the ground in rich soil (rarely on strongly decayed wood) (Vellinga 2001a-f; Lange 2008a-h). All of them are represented in Polish biota, although many widespread and common European species have not been hitherto recorded from Poland. Many other species have been hitherto mentioned from single, often historical localities.

\section{MATERIAL AND METHODS}

The paper presents 47 species of genera Cystolepiota, Echinoderma, Lepiota, Leucoagaricus, Leucocoprinus, Macrolepiota and Melanophyllum, found during mycological studies conducted in the years 2008-2010, which are new to Poland (18 species) or known only from scattered localities. For the species new to Poland short descriptions, based on the specimens examined and literature data, are given. The material collected was deposited in the herbarium of Field Station of the Institute for Agricultural and Forest Environment, Polish Academy of Sciences (ZBŚRiL), herbarium of the Institute of Botany, Polish Academy of Sciences (KRAM-F) or in the private herbarium of one of the authors (BG) (BGF). Unless otherwise indicated, names are given according to the Funga Nordica (Lange 2008a-h) and threatened categories according to Wojewoda and Ławrynowicz (2006). Native plant names are given according to Mirek et al. (2002). The information about the species distribution is given after Wasser (1995), Vellinga (2001a-f), Gminder (2003), Škubla (2003), Legon et al. (2005), Zelený (2006), Kosakyan et al. (2008a,b), Kumar, Manimohan (2009a,b) Lange (2008a-h) and monographic papers. The material was studied according to standard methods used in the taxonomy of fungi. The microscopic structures were examined in dried material, mounted in Congo Red (1\% solution of dye in $10 \%$ ammonia) or $10 \%$ ammonia and in fresh material mounted in water, using Bresser Bino Researcher microscope. Drawings of microcharacters were made from microphotographs taken with Nikon Coolpix 950 Digital Camera. All measurements were made directly through the microscope under an oil immersion objective. The spore dimensions were established from measurements of 30 randomly selected, well formed spores (the enormously big or small as well as deformed or atrophied ones were excluded from analysis). For basidia, cystidia and pileipellis the extreme size values were presented. For basidia and pileipellis hyphae dimensions were obtained after measuring of 20 elements. Because of huge variability of cystidia size, at least 50 measurements were taken. Literature data of spores and hyphae dimensions were given after Vellinga (2001a-f), unless mentioned otherwise. 


\section{RESULTS}

\section{LIST OF SPECIES}

\section{Cystolepiota Singer}

Hitherto only four Cystolepiota species have been found in Poland (one species C. seminuda (Lasch) Bon - is common within this area ; Wojewoda 2003, Kujawa 2011); in Germany and North Europe seven, in Czech Republic - four, in Slovakia five species have been recorded until now (Gminder 2003; Škubla 2003; Zelený 2006; Lange 2008b).

\section{Cystolepiota adulterina (F.H. Møller) Bon}

DESCRIPTION AND ICONOGRAPHy: Canduso, Lanzoni (1990): 85-88 \& 634, Fig. 8 \& Tab. 2c; Rald et al. (1992): 34; Breitenbach, Kränzlin (1995): Vol. 4, Fig. 210 (as C. hetieri); Vellinga, Huijser (1998a): 515519 \& 522, Fig. 2a \& 3a; Ludwig (2000): 35, Tab. 33:19.7; Ludwig (2001): 105-106; Vellinga (2001e): 157; Gminder (2003): 51.

Localities: 1. "Szczyt Wieżycy" reserve, near Szymbark village, few basidiocarps on soil in beech forest; ATPOL: CB-07; 19.10.2006; leg. M. Wantoch-Rekowski, det. B. Gierczyk; BGF/BF/MWR/061019/0001. 2. Białowieska Primeval Forest, Białowieża National Park, compartment no. 371 and 399, in Tilio-Carpinetum, a dozen of basidiocarps on rich soil among nitrophilous herbaceous plants (Urtica dioica, Chelidonium maius), in scattered groups; ATPOL: GC-55; 15.09.2009, 16.09.2009, 19.09.2009; leg. B. Gierczyk, A. Kujawa, det. B. Gierczyk; BGF/090915/0001, BGF/090916/0006, BGF/090919/0014.

DistRIBUTION AND REMARKs: Species rare and scattered in Europe and Asia (Caucasus), found mainly in Mediterranean and boreal regions, growing in deciduous forests (Vellinga 2001e; Gminder 2003; Legon et al. 2005). It is known on the territory of Poland only from Puszcza Bukowa forest near Szczecin and Babia Góra massif (Wojewoda 2003).

\section{Cystolepiota bucknallii (Berk. \& Broome) Singer \& Clémençon}

Description AND iCONOGRAPHy: Canduso, Lanzoni (1990): 108-110 \& 638, Fig. 15 \& Tab. 6b; Rald et al. (1992): 34; Kelderman (1994): 30-31; Breitenbach, Kränzlin (1995): Vol. 4, Fig. 209; Ludwig (2000): 34, Tab. 32:19.3A\&B; Ludwig (2001): 102; Vellinga (2001e): 158-159, Fig. 125; Gminder (2003): 51-53.

Localities: Białowieża Primeval Forest, Białowieża National Park, compartment no. 370, in Tilio-Carpinetum, a dozen of basidiocarps on rich soil among $U r$ tica dioica, scattered; ATPOL: GC-55; 16.09.2009; leg., det. B. Gierczyk, A. Kujawa; BGF/090916/0007, BGF/090916/0010.

DisTRIBUTION AND REMARKS: Not common but widespread European species, found in many countries, with a concentration of localities in temperate regions, mentioned also from North America (Wasser 1985; Vellinga 2001e, 2007; Gminder 2003; Legon et al. 2005). Growing mainly in deciduous forest on nitrogen-rich soil; hitherto known from four localities in Poland - "Ostrów Panieński" reserve near Chełmno, Pieniny National Park, "Bory Tucholskie" forests and "Buki nad Jeziorem Lutomskim" reserve (Lawrynowicz 2001; Wojewoda 2003; Bujakiewicz, Springer 2009). 


\section{Cystolepiota hetieri (Boud.) Singer}

DesCRIPTION AND ICONOGRAPHY: Canduso, Lanzoni (1990): 94-97 \& 636, Fig. 11 \& Tab. 4; Rald et al. (1992): 34; Kelderman (1994): 36-37; Vellinga, Huijser (1998a): 519 \& 521-524, Fig. 2e \& 3d; Ludwig (2000): 35, Tab. 33:19 9A-C; Ludwig (2001): 107-108; Vellinga (2001e): 156, Fig. 122; Gminder (2003): 53-54.

LocaLITIES: Beskid Mały Mts, "Wapiennik w Inwałdzie" forest, on the rich, calcareous soil near the stream, seven basidiocarps in the wood belonging to TilioCarpinetum association; ATPOL: DF-85; 11.10.2007; leg. P. Chachuła, det. B. Gierczyk; BGF/BF/071011/0001.

DISTRIBUTION AND REMARKS: Not common but widespread species in Europe, known mainly from temperate regions, occurring mainly on loamy, lime and nutrient rich soils in deciduous forests (Wasser 1985; Vellinga 2001e; Gminder 2003; Legon et al. 2005). Mentioned also from Asia - Caucasus and Primorsky Krai (Wasser 1985). Hitherto found on four localities in Poland - Uniejów, "Ostrów Panieński" reserve near Chełmno, Tatry National Park and Babia Góra massif (Wojewoda 2003, Bujakiewicz 2011).

DESCRIPTION AND ICONOGRAPHY: Canduso, Lanzoni (1990): 104-107 \& 637, Fig. 14 \& Tab. 5c (as $C$. luteocystidiata); Kelderman (1994): 38-39 (as C. luteocystidiata); Vellinga, Huijser (1998a): 518-521 \& 522, Fig. 2b-d \& 3b-c (as C. cystidiosa); Ludwig (2000): 33, Tab. 31:19.2A \& B (as C. luteocystidiata); Ludwig (2001): 101-102 (as C. luteocystidiata); Vellinga (2001e): 155-156, Fig. 121; Gminder (2003): 53 (as $C$. cystidiosa); Vellinga (2006): 226-228, Fig. 1 \& 2 ; Kumar, Manimohan (2009b): 282-283.

A

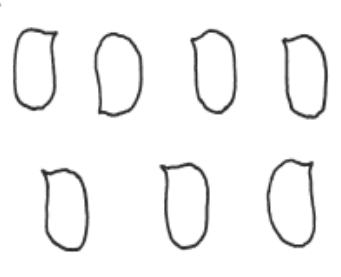

$\mathrm{B}-$

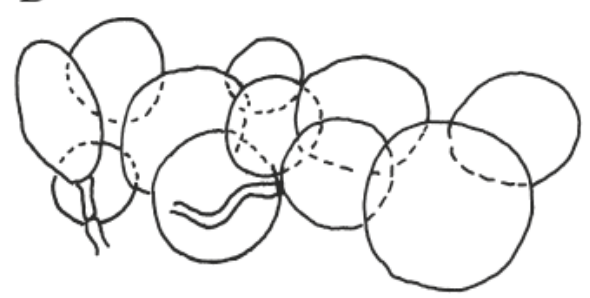

C

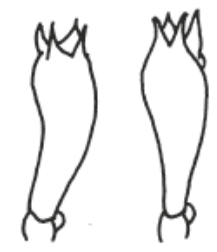

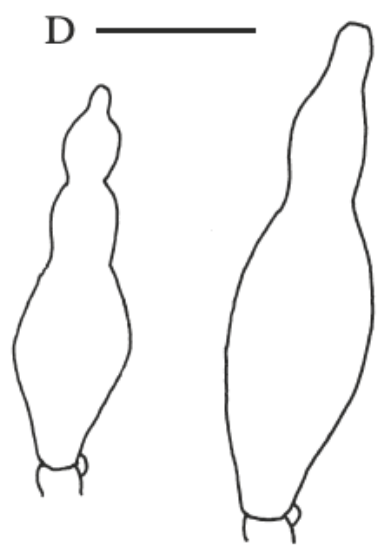
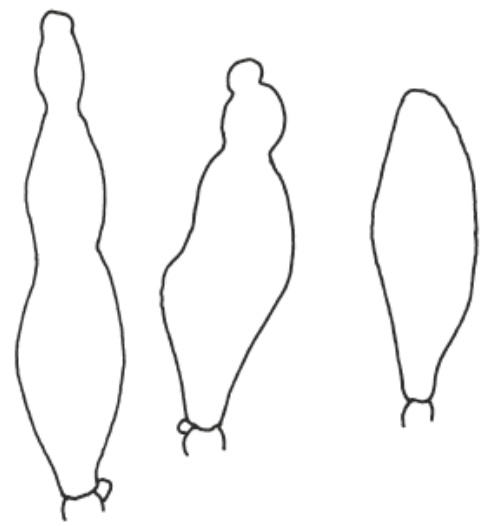

Fig. 1. Cystolepiota fumosifolia microcharacters: A - spores; B - pileus covering; C - basidia; $\mathrm{D}-$ cheilocystidia. Scale bars $=10 \mu \mathrm{m}$. 
Synonyms: Lepiota fumosifolia Murrill; Lepiota cystidiosa A.H. Sm.; Cystolepiota cystidiosa (A.H. Sm.) Bon; Lepiota luteocystidiata D.A. Reid; Cystolepiota luteocystidiata (D.A. Reid) Bon; Lepiota lycoperdoides Kreisel; Cystolepiota cystidiosa var. lycoperdoides (Kreisel) Bon

Macroscopic AND Microscopic FeATURES: Pileus 20-35 mm in diameter, first spherical then plano-convex, covered with yellowish-brown to reddish-brown, acute, granular pyramidal squamules and warts. Lamellae moderate crowded, free, creamcoloured, with dark spots in old specimens. Stipe up to $50 \times 4.5 \mathrm{~mm}$, cylindrical, covered with yellowish-brown fibrils and floccose patches, discolouring brown when touched. Spores ellipsoid or cylindrical, colourless, with slightly thickened walls, 4.0$5.5 \times 2.0-3.0 \mu \mathrm{m}($ lit. 3.5-5.5(6.0) $\times$ 2.0-3.0 $\mu \mathrm{m})$, without iodine reaction. Basidia 4-spored, 14-22 × 4.5-7 $\mu \mathrm{m}$ (lit. 12.5-20 × 4.5-6.5 $\mu \mathrm{m}$ ). Lamellar edge sterile, covered with yellow drops. Cheilocystidia variable in shape, fusoid and clavate, often with long moniliform neck or apical capitulum, 15-40 × 7-11 $\mu$ m (lit. 15-40(50) $\times$ 6.5-12 $\mu \mathrm{m})$, medium to thick-walled, often with yellow content or exudate. Pleurocystidia abundant, clavate, usually without moniliform excrescences, with yellow (in ammonia green-yellow) content, visible on the lamella surface as yellow dots. Pileus covering composed from globose elements, up to $80 \mu \mathrm{m}$ in diameter, thin-walled, with yellowish pigment. Clamp-connections present in all tissues.

LocAlities: 1. Otowo near Lusowo village, in deciduous, moist forest near allotments, very numerous, on rich soil under Coryllus avellana, Populus tremula and Alnus glutinosa; ATPOL: BD-07; 28.08.2010; leg., det. B. Gierczyk; BGF/ BG/100828/0003. 2. "Uroczysko Marcelin" forest in western part of Poznań city, along the road near Junikowski Stream, at the margin of the wood belonging to Fraxino-Alnetum association, few basidiocarps on wet, rich soil under Populus tremula; ATPOL: BD-08; 26.09.2009, 25.08.2010; leg., det. B. Gierczyk; BGF/090926/0008, BGF/BF/100825/0002. 3. Warsaw city, Polish Academy of Sciences Botanical Garden - Centre for Biological Diversity Conservation in Powsin, a dozen of basidiocarps in the greenhouses with collection of tropical (near Acalypha wilkesiana, Acokanthera oblongifolia, Asplenium nidus, Cyathea smithii, Diffenbachia sp., Dioscorea macroura, Ficus nitida, Fittonia verschaffeltii, Grevillea robusta, Hibiscus sp., Hoffmannia sp., Pilea sp., Strelitzia regina, Zamia furfuracea), subtropical (Impatiens niamniamensis, Ruscus hypophyllum) and xerophytic plants (Aloe vera, A. claviflora); ATPOL: ED37; 01.03.2010; 29.03.2010, 12.04.2010, 19.04.2010, 10.05.2010, 24.05.2010; leg. A. Szczepkowski, det. B. Gierczyk, A. Szczepkowski; BGF/BF/100301/0001, BGF/BF/ ASz/100329/0001, BGF/BF/ASz/100329/0002, BGF/BF/ASz/100329/0003, BGF/BF/ ASz/100412/0001, BGF/BF/ASz/100412/0002, BGF/BF/ASz/100419/0001, BGF/BF/ ASz/100419/0002, BGF/BF/ASz/100419/0003, BGF/BF/ASz/100419/0004, BGF/BF/ ASz/100510/0002, BGF/BF/ASz/100524/0001. 4. Kaźmierski Landscape Park, 1.5 km E from Parchatka village, on the loamy soil in the wood belonging to Tilio-Carpinetum association, one basidiocarp; ATPOL: FE-13; 02.09.2009; leg. B. Mazurek, det. B. Gierczyk; BGF/BF/090902/0002.

Distribution AND REMARKs: Rare species known from scattered localities in Europe (Denmark, Germany, Netherlands), North America and Indian subcontinent, where was found in deciduous forest on nitrogen-rich soil, known also from greenhouses (Vellinga 2001e, 2006, 2007; Gminder 2003; Lange 2008b; Kumar, 
Manimohan 2009b). Species new to Poland, easy to recognize because of characteristic pileus covering, moniliform cystidia with yellow content and non-dextrinoid spores.

\section{Cystolepiota moelleri Knudsen}

Fig. 2

DESCRIPTION AND ICONOGRAPHY: Canduso, Lanzoni (1990): 98-100 \& 637, Fig. 12 \& Tab. 5a; Kelderman (1994): 40-41; Vellinga, Huijser (1998a): 519, 522 \& 524-525, Fig. $2 f$ \& 3e; Ludwig (2000): 34, Tab. 32:19.6; Ludwig (2001): 104-105; Vellinga (2001e): 157-158, Fig. 123.

Synonyms: Lepiota rosea Rea; Cystolepiota rosea (Rea) Bon; Cystolepiota rosella M.M. Moser.

MACROSCOPIC AND MICROSCOPIC FEATURES: Pileus small to medium, up to $40 \mathrm{~mm}$ in diameter, at first hemispherical, then plane, densely covered with small, acute, pulverulent pink or red-brown squamules and warts. Lamellae crowded, free, white to pale cream. Stipe up to $40 \times 5 \mathrm{~mm}$, cylindrical with slightly widened base, covered with pink or red-brown fibrils, flocci and granules, with pale pink to vinaceous-red background. Spores cylindrical or oblong, 4.0-5.3 × 2.4-3.0 $\mu \mathrm{m}$ (lit. 4.0-5.5 × 2.5-3.0 $\mu \mathrm{m})$, thin-walled, colourless, without iodine reaction. Lamellar edge sterile. Basidia 4-spored, 15-30 $\times$ 4-7 $\mu \mathrm{m}$ (lit. 16-26 $\times(3.5) 5.0-7.5 \mu \mathrm{m})$. Cheilocystidia abundant, colourless, clavate, narrowly clavate or obovate 15-38 $\times$ 6.5-14 $\mu \mathrm{m}$ (lit. 15-35(39) $\times 7.0-15 \mu \mathrm{m}$ ), often with apical excrescence (cylindrical, moniliform or branched). Pleurocystidia absent. Pileus covering built up from spherical to ellipsoid hyphae, up to $65 \mu \mathrm{m}$ in diameter, with $0.2-0.7 \mu \mathrm{m}$ thick walls and red-brown pigment. Clamps present in all tissues.
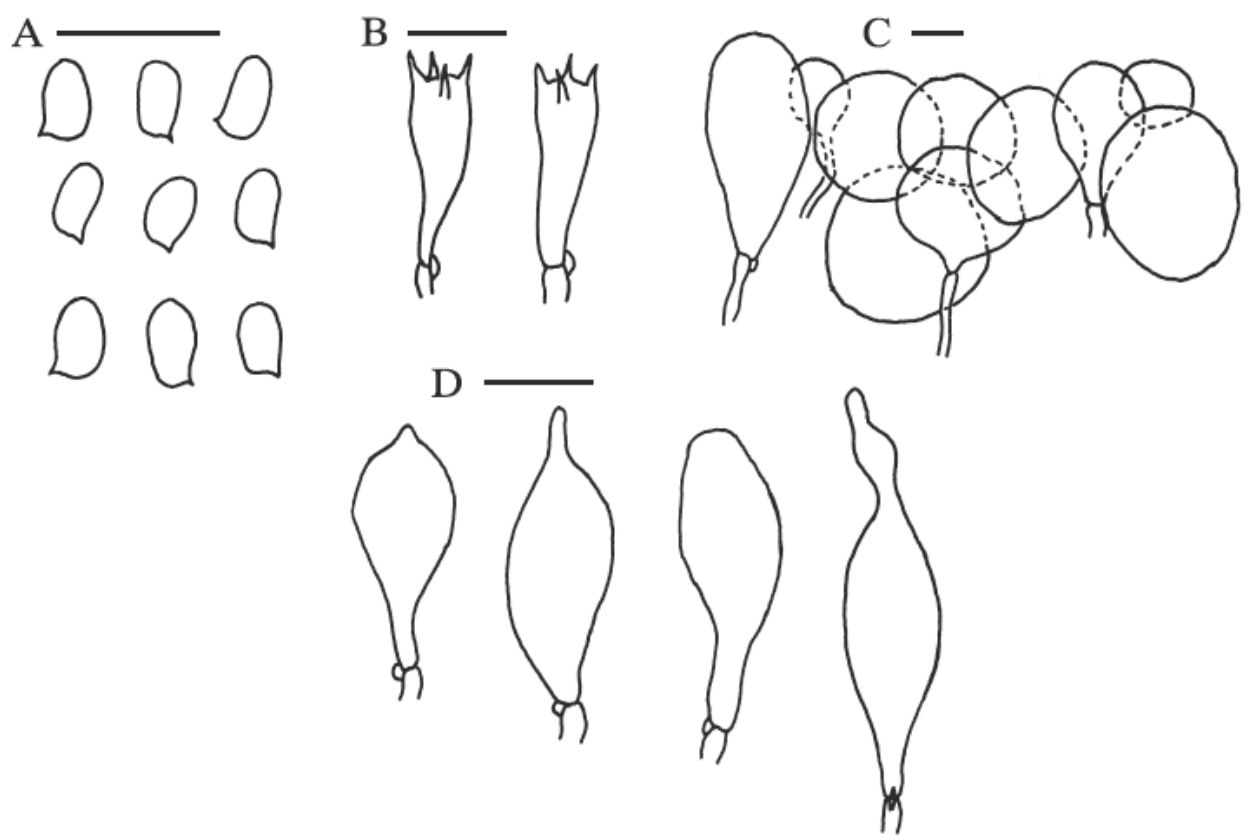

Fig. 2. Cystolepiota moelleri microcharacters: A - spores; B - basidia; C - pileus covering; $\mathrm{D}$ - cheilocystidia. Scale bars $=10 \mu \mathrm{m}$. 
Localities: Beskid Mały Mts, "Wapiennik w Inwałdzie" forest, on the rich, calcareous soil, two basidiocarps in the mixed wood (Fraxinus excelsior, Acer pseudoplatanus, Abies alba, Betula sp., Sambucus nigra); ATPOL: DF-85; 20.09.2007; leg. P. Chachuła, det. B. Gierczyk; BGF/BF/070920/0001.

DISTRIBUTION AND REMARKS: Rare species occurring in temperate regions of Europe, known from Netherlands, England, Germany, Italy and France (Canduso, Lanzoni 1990; Vellinga 2001e; Gminder 2003; Legon et al. 2005) as well as from North America (Vellinga 2006, 2007). Growing mainly in mixed forests, on loamy, calcareous, nitrogen-rich soil. Hitherto not mentioned from Poland. The characteristic colour and shape of cheilocystidia makes it easy to recognize. Macroscopically similar Echinoderma species have dextrinoid spores and different cystidia.

\section{Cystolepiota petasiformis (Murrill) Vellinga}

Fig. 3

DESCRIPTION AND ICONOGRAPHY: Canduso, Lanzoni (1990): 356-360 \& 673, Fig. 73, 74 \& Tab. 41 (as Leucoagaricus pulverulentus); Kelderman (1994): 34-35 (as C. pulverulenta); Ludwig (2000): 35, Tab. 33:19.10 (as C. pulverulanta); Ludwig (2001): 108-109 (as C. pulverulanta); Vellinga (2001e): 159-160, Fig. 126 (as C. pulverulanta); Vellinga (2006): 228-230, Fig. 3; Vellinga (2007): 1; Kumar, Manimohan (2009b): 283.

SyNONYMS: Lepiota petasiformis Murrill; Lepiota pulverulenta Huijsman; Leucoagaricus pulverulentus (Huijsman) Bon; Leucoagaricus pulverulentus (Huijsman) M.M. Moser; Cystolepiota pulverulenta (Huijsman) Vellinga; Pulverolepiota pulverulenta (Huijsman) Bon; Leucoagaricus pulverulentus f. minimus Bon, Migl. \& Brunori; Cystolepiota pulverulanta f. minima (Bon, Migl. \& Brunori) La Chiusa; Pulverolepiota pulverulanta f. minima (Bon, Migl. \& Brunori) Bon

MACroscopic AND Microscopic FEATURES: Pileus small to medium size, up to 50 $\mathrm{mm}$, first conical or conico-convex, then plane with obtuse papilla, white or creamcoloured, becoming pink or orange-brown with age or when touched. Stipe up to 65 $\times 5.5 \mathrm{~mm}$, cylindrical, with equal or subbulbous base. Stem apex subglabrous, rest of the stem and the pileus surface covered by the thick, easy removable, flocculose or pulverulent layer, forming warts and floccules. Lamellae free, crowded, white. Spores ellipsoid to ovoid, delicate rough, slightly dextrinoid, 3.5-5.0 $\times$ 2.5-3.5 $\mu \mathrm{m}$ (lit. 3.5-6.0 × 2.0-3.5 $\mu \mathrm{m}$ ). Basidia 4-spored, 15-23 × 4.5-8.0 $\mu \mathrm{m}$ (lit. 13-25 × 4.0-7.5

A

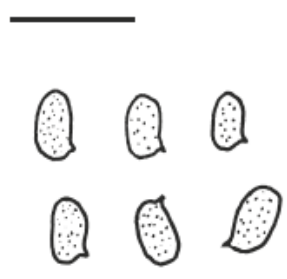

$\mathrm{B}$

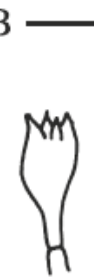

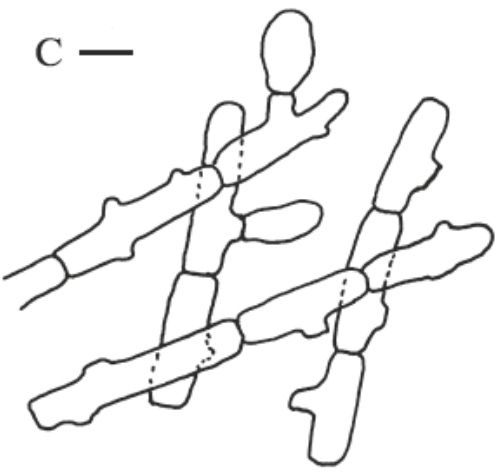

Fig. 3. Cystolepiota petasiformis microcharacters: A - spores; B - basidia; C - pileus covering. Scale bars $=10 \mu \mathrm{m}$. 
$\mu \mathrm{m})$. Hymenial cystidia absent. Velar cells elongate, inflated, partially branched and catenulate, with brownish encrustations. Clamps absent in all tissues.

Localities: Puszcza Zielonka Landscape Park, a dozen of basidiocarps on rich, moist soil, $1 \mathrm{~km} \mathrm{~S}$ from Lopuchowo village, among Urtica dioica, in mixed forest; ATPOL: CC-80; 12.09.2010; leg., det. B. Gierczyk; BGF/BG/100912/0003.

DiSTRIBUTION AND REMARKS: Very rare but widespread species occurring mainly in Mediterranean and temperate regions of Europe, preferring deciduous forests, growing on loamy, nitrogen-rich, moist soil (Vellinga 2001e; Legon et al. 2005). According to Vellinga (2001e) this species reach its northern limit in Netherlands and Germany but Wasser (1980) gives the localities from Finland, Sweden and Petersburg district (Russia). Known also from North America and Indian subcontinent (Vellinga 2006, 2007; Kumar, Manimohan 2009b). Hitherto not mentioned from Poland. Very characteristic and easy to recognize in the field because of mealy layer on pileus and stipe. Similar to Cystolepiota sistrata but significantly bigger and firmer. The most important microscopic characters are the absence of cystidia and shape of pileus covering elements.

\section{Echinoderma (Bon) Bon}

The genus Echinoderma is included by many authors (e.g.: Wojewoda 2003) into the genus Lepiota (as the section Echinacea Fayod). From Poland only five Echinoderma species were mentioned, the most common within this area is Echinoderma aspera (Pers.) Bon (Wojewoda 2003, Kujawa 2011). In neighbour countries 10 species were found - 9 in Germany and Nordic Countries, 7 in Slovakia, 5 in Czech Republic (Gminder 2003; Škubla 2003; Zelený 2006; Lange 2008c).

\section{Echinoderma calcicola (Knudsen) Bon}

Description AND ICONOGRAPHy: Canduso, Lanzoni (1990): 131-134 \& 641, Fig. 18 \& Tab. 9a (as Lepiota calcicola); Kelderman (1994): 46-47 (as L. calcicola); Breitenbach, Kränzlin (1995): Vol. 4, Fig. 217 (as L. calcicola); Heilmann-Clausen (1996b): 32-34 (as L. calcicola); Vellinga (2001d): 146-147, Fig. 114 (as L. calcicola); Gminder (2003): 59-60; Kasuya, Knudsen (2003): 327-328, Fig. 1 \& 2 (as L. calcicola).

Localities: Bieszczady Mts, Bieszczady National Park, Ustrzyki Górne village, S slopes of Połonina Caryńska massif, near tourist trail, one basidiocarp in beech forest belonging to Dentario glandulosae-Fagetum association, on the ground; ATPOL: FG-69; 07.09.2008; leg. T. Pachlewski, det. B. Gierczyk; BGF/080907/0001, ZBŚRiL 26/BdPN/07.09.08.

DistRIBUTION AND REMARKs: Widespread and rare European species, known from scattered localities in south and central part of Europe (Vellinga 2001d; Gminder 2003) and Asia - Japan (Kasuya, Knudsen 2003). Occurring on humus-rich, calcareous soil in deciduous wood. In Poland found only twice, near Elbląg and in botanical garden in Poznań (Wojewoda 2003).

Echinoderma carinii (Bres.) Bon

Fig. 4

Description AND ICONOGRAPHY: Canduso, Lanzoni (1990): 135-138 \& 640, Fig. 19 \& Tab. 8b (as Lepiota carinii); Kelderman (1994): $48-49$ (as L. carinii); Vellinga (2001d): 149-150, Fig. 117 (as L. carinii).

SyNONYMS: Lepiota carinii Bres.

MACROSCOPIC AND MicRosCoPIC FEATUREs: Pileus medium-size, up to $45 \mathrm{~mm}$, first hemispherical, then plane with low umbo, pale brown or yellowish brown with dark 


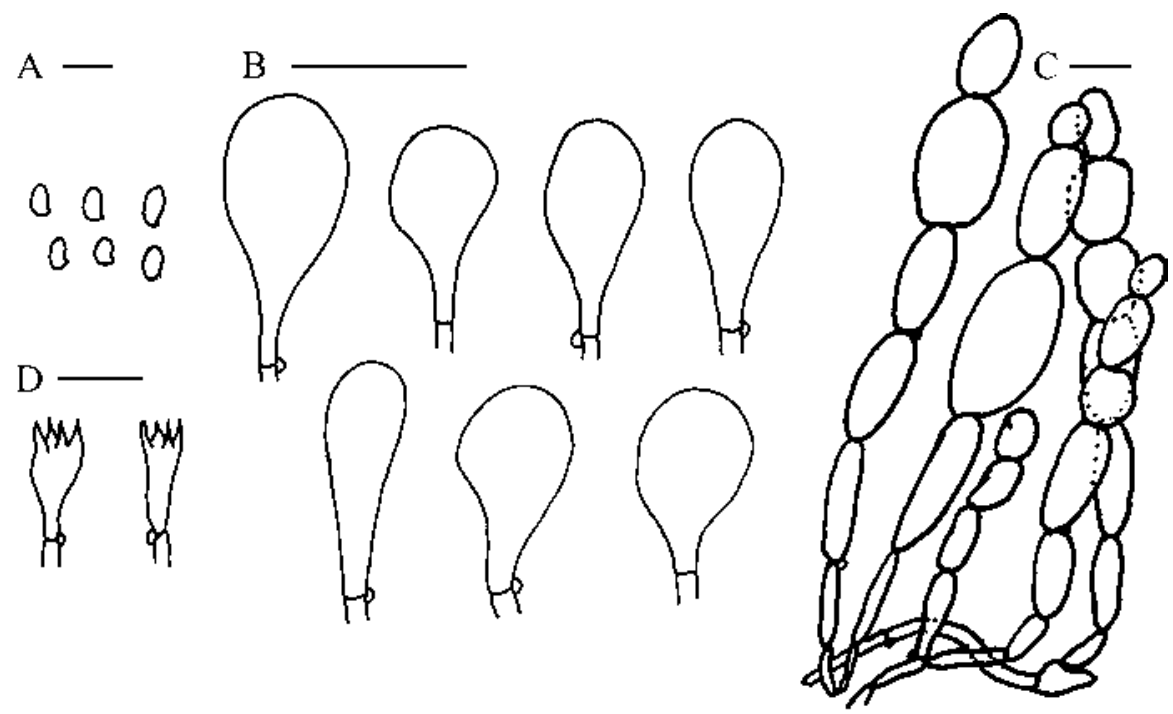

Fig. 4. Echinoderma carinii microcharacters: A - spores; B - cheilocystidia; C - pileus covering; $\mathrm{D}$ - basidia. Scale bars $=10 \mu \mathrm{m}$.

brown, acute, pyramidal warts and squamules. Stipe rather short, up to $60 \times 7 \mathrm{~mm}$, cylindrical with slightly enlarged base, whitish or pale yellow-brown, with brown girdles in lower part. Annulus woolly. Lamellae crowded, free, white, becoming brownspotted with age. Spores ellipsoid to oblong, dextrinoid, 3.5-4.5 × 2.5-3.0 $\mu \mathrm{m}$ (lit.

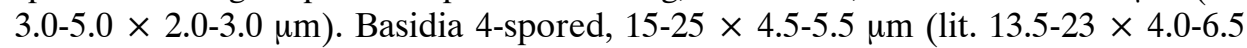
$\mu \mathrm{m})$. Cheilocystidia scattered, clavate to somewhat cylindrical, $15-25 \times 6.0-9.0 \mu \mathrm{m}$ (lit. 16-33 $\times 5.0-8.5 \mu \mathrm{m}$ ). Pleurocystidia absent. Pileal squamules built from chains of spherical or ellipsoid, yellow-brown hyphae, terminal elements up to $25 \mu \mathrm{m}$ in diameter. Clamp-connections present.

LocAlities: Between Konarzewo village and Podłozice forest ranger's lodge, four basidiocarps on rich soil, under nitrophilous shrubs along field road (Prunus spinosa, Crataegus sp., Rosa canina, Rubus sp.); ATPOL: BD-07; 04.09.2010; leg., det. B. Gierczyk; BGF/BF/100904/0014, BGF/BF/100904/0015.

DisTRIBUTION AND REMARKs: Very rare species in Europe, known from Italy, Netherlands, Denmark, Czech Republic and Slovakia. It grows in deciduous woods and parks, on rich, loamy or clayey soil (Vellinga 2001d; Gminder 2003). Hitherto not mentioned from Poland. Echinoderma species are often difficult to recognize. E. carinii is characterized by following combination of characters: basidiocarps firm with short stipe, dextrinoid spores, clavate cheilocystidia and rather small pileus covering elements.

\section{Echinoderma perplexa Knudsen}

DESCRIPTION AND ICONOGRAPHY: Canduso, Lanzoni (1990): 147-150, Fig. 22 (as Lepiota perplexa); Kelderman (1994): 44-45 (as L. perplexa); Breitenbach, Kränzlin (1995): Vol. 4, Fig. 233 (as L. perplexa); Vellinga (2001d): 145-146, Fig. 113 (as L. perplexa); Pearson (2007): 66, Fig. 1 (as L. perplexa). 
Localities: Olsztyn, Częstochowa district, Sokole Góry hills, one basidiocarp in beech forest on calcareous soil; ATPOL: DE-94; leg. K. Kołodziejczyk, det. B. Gierczyk; BGF/BF/KK/101030/0001.

Distribution AND REMARKS: Widespread but rare European species, with the centre of its distribution in the temperate regions, growing on rich soil in deciduous woods and parks (Vellinga 2001d; Gminder 2003; Legon et al. 2005). In Poland hitherto found only once, in Białowieżai National Park (Wojewoda 2003).

Echinoderma pseudoasperula (Knudsen) Bon

Fig. 5

Description AND ICONOGRAPHY: Canduso, Lanzoni (1990): 151-154 \& 642, Fig. 23 \& Tab. 10b (as $L$. pseudoasperula); Rald et al. (1992): 35; Kelderman (1994): 56-57 (as L. pseudoasperula); Vellinga (2001d): 150, Fig. 118 (as Lepiota pseudoasperula); Malysheva (2005): 365-366, Fig. 1 \& 2.

Synonyms: Cystolepiota pseudoasperula Knudsen; Lepiota pseudoasperula (Knudsen) Knudsen

MACROSCOPIC AND MICROSCOPIC FEATURES: Pileus small, 10-25 mm, hemispheric when young, then plano-convex, pinkish-brown to reddish-brown, with $1 \mathrm{~mm}$ high, pointed, squamules. Lamellae free, moderately crowded, cream. Stipe up to $35 \times$ $3 \mathrm{~mm}$, cylindrical, in lower part cowered with squamules, concolours with that on pileus, at apex almost glabrous. Spores cylindrical, dextrinoid, 4.0-5.5 $\times 2.0-3.0 \mu \mathrm{m}$ (lit. (3.5)4.0-5.0(6.0) $\times 2.0-3.0 \mu \mathrm{m})$. Basidia 4-spored, cylindrical to clavate, 17-25 $\times$ 4-7 $\mu \mathrm{m}$ (lit. 14-24 $\times$ 4.5-6.5 $\mu \mathrm{m}$ ). Cystidia absent. Pileal squamules composed from

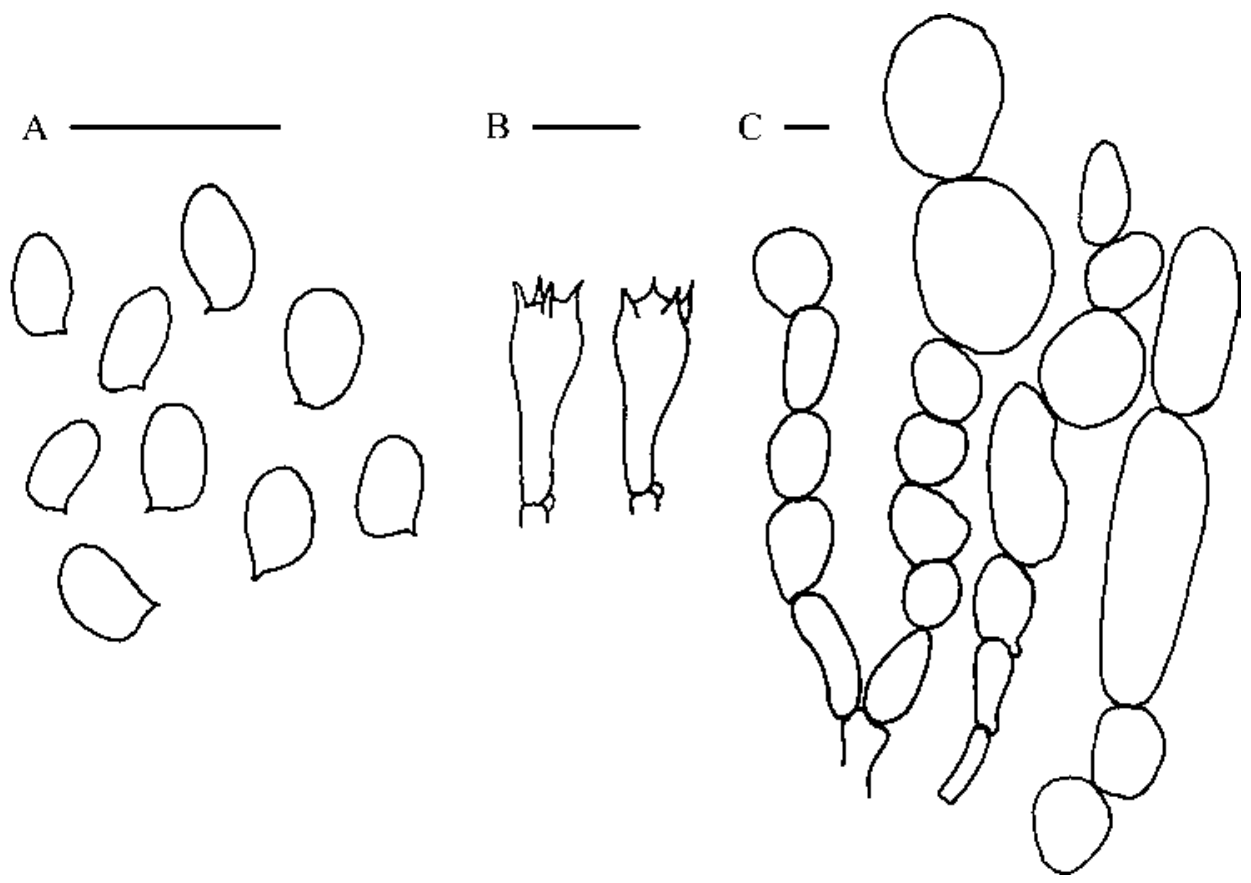

Fig. 5. Echinoderma pseudoasperula microcharacters: A - spores; B - basidia; D - pileus covering. Scale bars $=10 \mu \mathrm{m}$. 
chains of elongated to globoid elements, terminal ones up to $50 \mu \mathrm{m}$ in diameter. Clamps present in all tissues.

LocAlities: Beskid Mały Mts, "Wapiennik w Inwałdzie" forest, on the calcareous soil mixed with ash, 12 basidiocarps on the margin of the mixed wood (Fraxinus excelsior, Acer pseudoplatanus, Betula sp.); ATPOL: DF-85; 01.10.2007; leg. P. Chachuła, det. B. Gierczyk; BGF/BF/071001/0002.

DistRIBUTION AND REMARKs: Very rare and scattered species in Europe, known from Netherlands, Norway, Italy, Denmark, Sweden, Germany, England and Russia (Vellinga 2001d; Gminder 2003; Legon et al. 2005; Malysheva 2005; Lange 2008c). It is known also from Indian subcontinent (Kumar, Manimohan 2009a). Until now not mentioned from Poland. As other Echinoderma species, it is difficult to recognize. Macroscopically characterized by slender, small basidiocarps. In the field easy to mistaken for Cystolepiota moelleri, but the absence of cheilocystidia and dextrinoid spores in E. pseudoasperula make these species easy to distinguish by microscopic characters.

\section{Lepiota (Pers.) Grey}

In literature only 25 species of genus Lepiota were mentioned from the territory of Poland (Wojewoda 2003; Kujawa 2011). Depending on the taxa classification assumed, 80-100 species from this genus were found in Europe (mainly in Mediterranean regions). In neighbour countries about 65 species occurs (60 in Germany, 34 in Nordic Countries, 24 in Slovakia, 30 in Czech Republic) (Gminder 2003; Škubla 2003; Zelený 2006; Lange 2008d).

Lepiota angustispora (Migl. \& Bizzi) Hauskn. \& Pidlich-Aigner

Fig. 6

Description AND IConography: Canduso, Lanzoni (1990): 166-167 \& 646, Fig. 27, Tab. 14 (as L. alba forma); Hausknecht, Pidlich-Aigener (2005): 42-43, 47 \& 51, Fig. 1d-f, 4.

SynONYMS: Lepiota alba forma Canduso \& Lanzoni; Lepiota alba var. angustispora Migl. \& Bizzi.

MACROSCOPIC AND MICROSCOPIC FEATURES: Cap medium, up to $45 \mathrm{~mm}$, at first campanulate, then plane, whitish, pale yellow to pale ocher, glabrous or with sparse, discrete, yellowish, adpressed squamules. Lamellae free, white, moderate distant. Stipe up to $70 \times 7 \mathrm{~mm}$, white, with floccose annular zone, in lower part white flocculose. Spores Boletus-shape, 8.0-11.5 × 3.5-4.2 $\mu \mathrm{m}$ (lit. 8-11(13.5) × 3.5-4(4.5) $\mu \mathrm{m}$; Hausknecht, Pidlich-Aigener (2005)). Basidia 4-spored, narrowly clavate, 25-45 $\times$ 8-13 $\mu \mathrm{m}$. Cheilocystidia variable, clavate, utriform, narrowly utriform or broadly fusiform, 18-22 × 7-9 $\mu \mathrm{m}$ (lit. 17-24 × 7-9 $\mu \mathrm{m}$; Hausknecht, Pidlich-Aigener (2005)). Pleurocystidia absent. Pileus covering composed from aseptate, straight, cylindrical elements, up to $220 \times 10 \mu \mathrm{m}$, very sparse short, clavate elements present.

LOCALITIES: 1. Between villages Stroczki and Gułtowy, at field road, one basidiocarp on rich soil under Fraxinus excelsior, Sambucus nigra, Prunus spinosa and Urtica dioica; ATPOL: CD-11; 05.09.2010; leg., det. B. Gierczyk; BGF/BF/100905/0001. 2. Warsaw city, Warsaw University of Life Sciences - SGGW park at the Nowoursynowska street, few basidiocarps on the ground under deciduous trees (Robinia sp., Carpinus betulus, Acer platanoides, A. pseudoplatanus, Aesculus hippocastanum, 

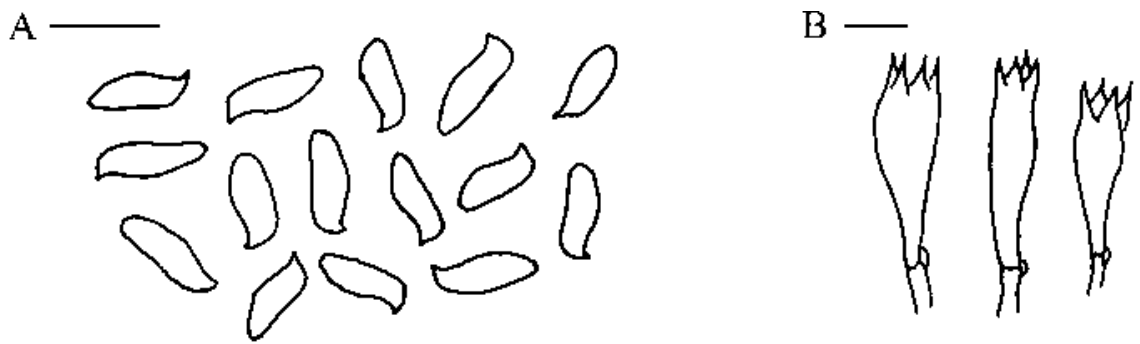

$\mathrm{C}-$
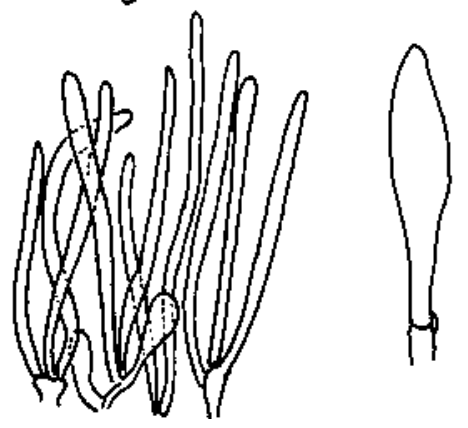

$\mathrm{D}$
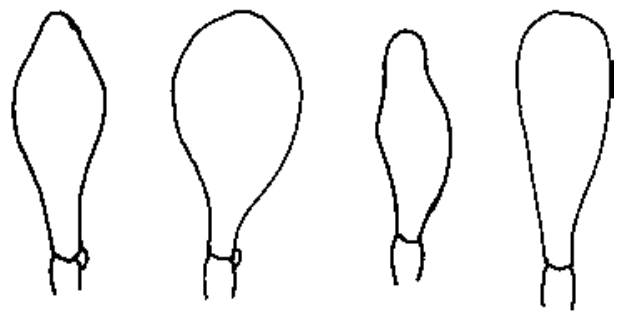

Fig. 6. Lepiota angustispora microcharacters: A - spores; $\mathrm{B}$ - basidia; $\mathrm{C}$ - pileus covering; $\mathrm{D}$ - cheilocystidia. Scale bars $=10 \mu \mathrm{m}$.

Quercus sp., Tilia sp., Fagus sylvatica, Ulmus laevis); ATPOL: ED-27; 11.10.2006; leg. A. Szczepkowski, det. B. Gierczyk; BGF/BF/061011/0001.

DistRIBUTION AND REMARKs: Very rare species, known only from Italy and Austria. First time recognized by Canduso and Lanzoni (1990) and described as a form of $L$. alba (Bress.) Sacc. without name proposed and then named by Migliozzi and Bizzi (1994) as L. alba var. angustispora. The treatment of this fungus as a subtaxon of $L$. alba is groundless because of significant differences in spores shape and dimensions (see Hausknecht, Pidlich-Aigener 2005). Hitherto it has been collected in warm, deciduous woods. Species new to Poland. Basidiocarps of this species are similar but less firm than that of $L$. erminea. The most important character is the Boletus-shape spores, shorter than $11 \mu \mathrm{m}$. Other species producing such spores have different pileus covering and basidiocarps colour.

Lepiota apatelia Vellinga \& Huijser

Fig. 7

Description AND ICONOGRAPHY: Vellinga, Huijser (1998b): 196-197, Fig. 1; Vellinga (2001d): 138-139, Fig. 105; Hausknecht, Pidlich-Aigener (2005): 43-44; Kosakyan et al. (2008b): 64-66, Fig. 3.

Macroscopic AND microscopic FeAtures: Pileus up to $35 \mathrm{~mm}$, at first campanulate, then plane with blunt umbo, covered with orange-brown or yellowish-brown, concentrically arranged, adpressed squamules and patches on whitish background, with small calotte in the centre (cap very similar to that of $L$. cristata). Lamellae moderate crowded, whitish to cream. Stipe up to $50 \times 3 \mathrm{~mm}$, cream-coloured, cylindrical, annulus absent. Spores ellipsoid 4.0-5.5 × 2.5-3.5 um (lit. 4.5-6.5 × 3.0-4.0 $\mu \mathrm{m})$, dextrinoid. Basidia 4-spored, narrowly clavate, 15-25 $\times$ 5-7 $\mu \mathrm{m}$ (lit. 15-27(32) $\times 5-8 \mu \mathrm{m})$. Lamella edge fertile. Cystidia absent. Pileus covering hymeniderm, built 

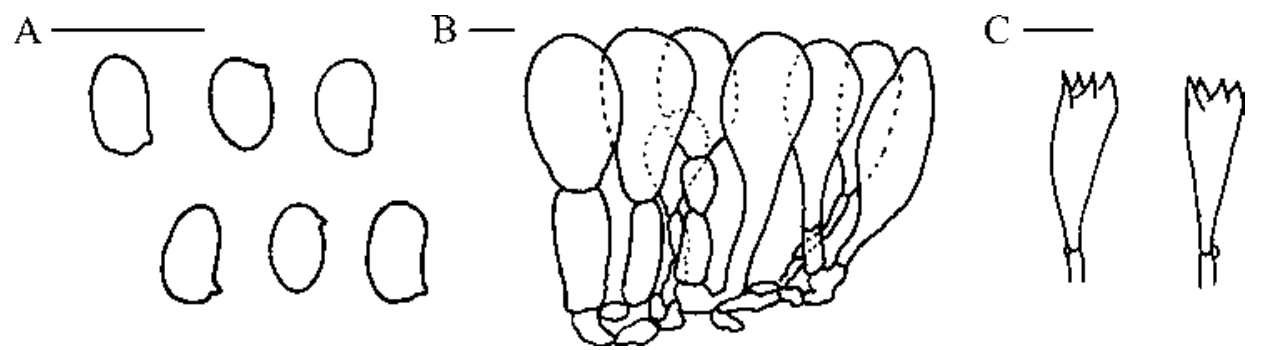

Fig. 7. Lepiota apatelia microcharacters: A - spores; B - pileus covering; C - basidia. Scale bars $=10 \mu \mathrm{m}$.

up from narrowly clavate or spherical elements up to $40 \times 20 \mu \mathrm{m}$, with brown, thickened walls. Clamps present. Smell of flesh was not checked.

Localities: 1. Kłomnice, Częstochowa district, one basidiocarp on the ground in mixed forest (Pinus sylvestris, Quercus sp., Betula sp.); ATPOL: DE-75; 26.07.2009; leg. K. Kołodziejczyk, det. B. Gierczyk; BGF/BF/090726/0001. 2. Garnek, Częstochowa district, few basidiocarps on soil in mixed forest (Pinus sylvestris, Quercus sp., Betula sp.) at the margin of fallow orchard; ATPOL: DE-76; 07.08.2010; leg. K. Kołodziejczyk, det. B. Gierczyk; BGF/BF/KK/100807/0001.

Distribution AND REMARKs: Species recently described by Vellinga \& Huijser (1998b), macroscopically similar to L. cristata and L. cristatoides. Only little information about its occurrence in Europe has been published - it is known from Netherlands, Italy, Austria and Germany, where it grows in deciduous woods and on mine waste heaps (Vellinga, Huijser 1998b; Vellinga 2001d; Hausknecht, Pidlich-Aigener 2005). It is known also from Asia - Israel (Kosakyan et al. 2008a,b). Species new to Poland. Spores of specimens examined are slightly smaller than specified in literature (closer to that of the L. cristatoides), but the others characters are in accordance with descriptions. The absence of a ring and dextrinoid spores indicates that the basidiomata found belongs to the L. apatelia.

\section{Lepiota boudieri Bres.}

DESCRIPTION AND ICONOGRAPHY: Canduso, Lanzoni (1990): 195-198, Fig. 35; Kelderman (1994): 74-75; Breitenbach, Kränzlin (1995): Vol. 4, Fig. 216; Vellinga (2001d): 132-133, Fig. 97; Tofts (2002): 125-126 \& 135, Fig. 12-13; Gminder (2003): 67-69.

LocAlities: 1. Beskid Mały Mts, "Wapiennik w Inwałdzie" forest, on the calcareous soil, 7 basidiocarps in deciduous wood (Fraxinus excelsior, Acer pseudoplatanus, Sambucus nigra, Betula sp., Euonymus sp.); ATPOL: DF-85; 01.10.2007; leg. P. Chachuła, det. B. Gierczyk; BGF/BF/071001/0003. 2. Białowieża Primeval Forest, Białowieża National Park, compartment no. 399A, two basidiocarps on rich-soil in Tilio-Carpinetum, among Urtica dioica; ATPOL: GC-55; 16.09.2009; leg., det. B. Gierczyk; BGF/090916/0009.

Distribution AND REMARKs: Species known from temperate zone of Europe and North America, growing on humus-rich soils, in woods and parks. Widespread and rather common (Vellinga 2001d; Gminder 2003; Legon et al. 2005). In Poland found only at sites (as L. fulvella): in Ojcowski National Park, Babia Góra massif, Bieniszew near Kazimierz Biskupi, Górzyca near Kostrzyn and "Buki nad Jeziorem 
Lutomskim" reserve (Wojewoda 2003, 2008; Bujakiewicz 2004, 2010, 2011; Bujakiewicz, Springer 2009).

\section{Lepiota brunneoincarnata Chodat \& C. Martin; V}

DESCRIPTION AND ICONOGRAPHY: Canduso, Lanzoni (1990): 248-252 \& 658, Fig. 47, Tab. 26a; Vellinga (2001d): 127, Fig. 91; Gminder (2003): 69-70.

LOCALITIES: Between Konarzewo village and Podłozice forest ranger's lodge, one basidiocarp on rich soil, under nitrophilous shrubs along field road (Prunus spinosa, Crataegus sp., Rosa canina, Rubus sp.); ATPOL: BD-07; 04.09.2010; leg., det. B. Gierczyk; BGF/BF/100904/0010.

DISTRIBUTION AND REMARKS: Species widespread but rare in Europe, growing in deciduous and mixed woods, but also in parks and gardens, on rich soil. Known also from Asia and North Africa (Wasser 1985; Vellinga 2001d; Gminder 2003; Legon et al. 2005; Kosakyan et al. 2008a). Hitherto in Poland found only on four localities (Wojewoda 2003; Kujawa, Gierczyk 2007; Łuszczyński 2007, 2008; Kujawa 2009)

\section{Lepiota ?cingulum Kelderman}

Fig. 8

DESCRIPTION AND ICONOGRAPHY: Kelderman (1994): 80-81; Heilmann-Clausen (1996a): 31-33; Vellinga (2001d): 131-132, Fig. 96; Tofts (2002): 126, 128, 131 \& 135, Fig. 14-15; Gminder (2003): 72-73; Pearson (2007): 69, Fig. 3.

MacrosCopic AND MicrosCopic FeAtURES: Pileus medium-size, up to $80 \mathrm{~mm}$, first hemispheric, then applanate with umbo, dark brown at centre, becoming paler towards margin, tomentose, covered with concentrically arranged, uplifted tufts, patches and squamules. Stipe up to $58 \times 10 \mathrm{~mm}$, cylindrical, with indistinctly bulbous base, whitish with pink tones, covered with girds of squamules in lower part. Lamellae white, free, rather distant. Spores with distinct spur, cylindrical, dextrinoid,
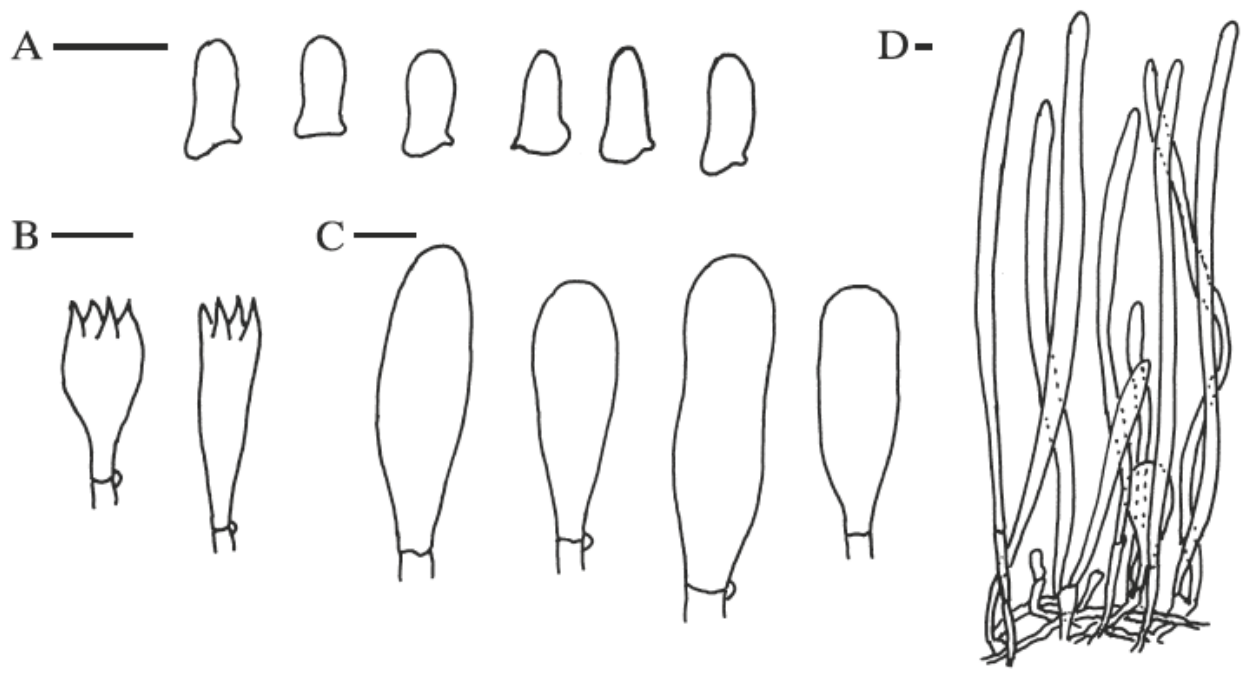

Fig. 8. Lepiota cingulum microcharacters: A - spores; B - basidia; C - cheilocystidia; $\mathrm{D}-$ pileus covering. Scale bars $=10 \mu \mathrm{m}$. 


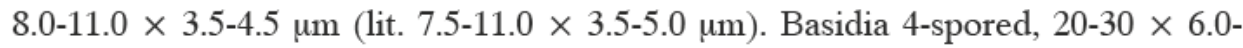
$8.5 \mu \mathrm{m}$ (lit. 21-39 $\times 6.0-10.0 \mu \mathrm{m}$ ). Cheilocystidia clavate to utriform, 20-70 $\times 8-22$ $\mu \mathrm{m}$ (lit. 17.5-90 × 7-24 $\mu \mathrm{m}$ ). Pleurocystidia absent. Pileus covering composed from erect, elongate, cylindrical elements 120-300 × 11-15 $\mu \mathrm{m}$ (lit. 100-400 × 12-16 $\mu \mathrm{m}$ ), with 0 -1 septa, dull drown. Underlayer made from brown, cylindrical, flexuous cells. Clamps present.

LOCALITIES: Between Konarzewo village and Podłozice forest ranger's lodge, one basidiocarp on rich soil, under nitrophilous shrubs along field road (Prunus spinosa, Crataegus sp., Rosa canina, Rubus sp.); ATPOL: BD-07; 04.09.2010; leg., det. B. Gierczyk; BGF/BF/100904/0005.

DISTRIBUTION AND REMARKS: Rare European species, known from scattered countries (Netherlands, Great Britain, France, Denmark), found in shrubs, mixed or deciduous woods, on clayey soil (Vellinga 2001d; Gminder 2003). Hitherto not mentioned from Poland. The studied specimen match well the description of $L$. cingulum, however because only one basidiocarp was found, we could not exclude that it represents some untypical form of other similar species of Lepiota sect. Stenosporae. The major differences between some species belonging to this section are macroscopical characters (i.e. colour of pileus covering, presence of the band on stipe, arrangement of squamules on cap surface). The L. cingulum is most likely to be confused with robust specimens of $L$. castanea and faded basidiocarps of the species from L. grangei group.

Lepiota aff. cortinarius J.E. Lange var. audreae D.A. Reid

Fig. 9

DESCRIPTION AND ICONOGRAPHY: Canduso, Lanzoni (1990): 204-205 \& 651, Tab. 19b; Kelderman (1994): 62-63; Vellinga (2001d): 120-121, Fig. 84a; Gminder (2003): 74-75; Kosakyan et al. (2008a): 358359, Fig. 2.
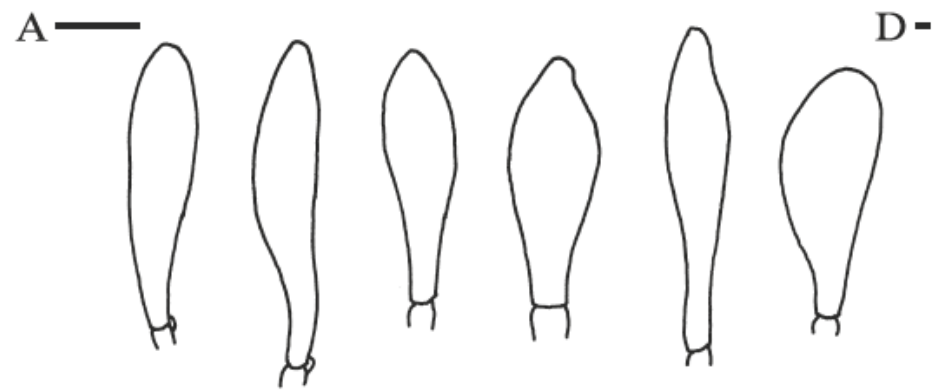

\section{B}
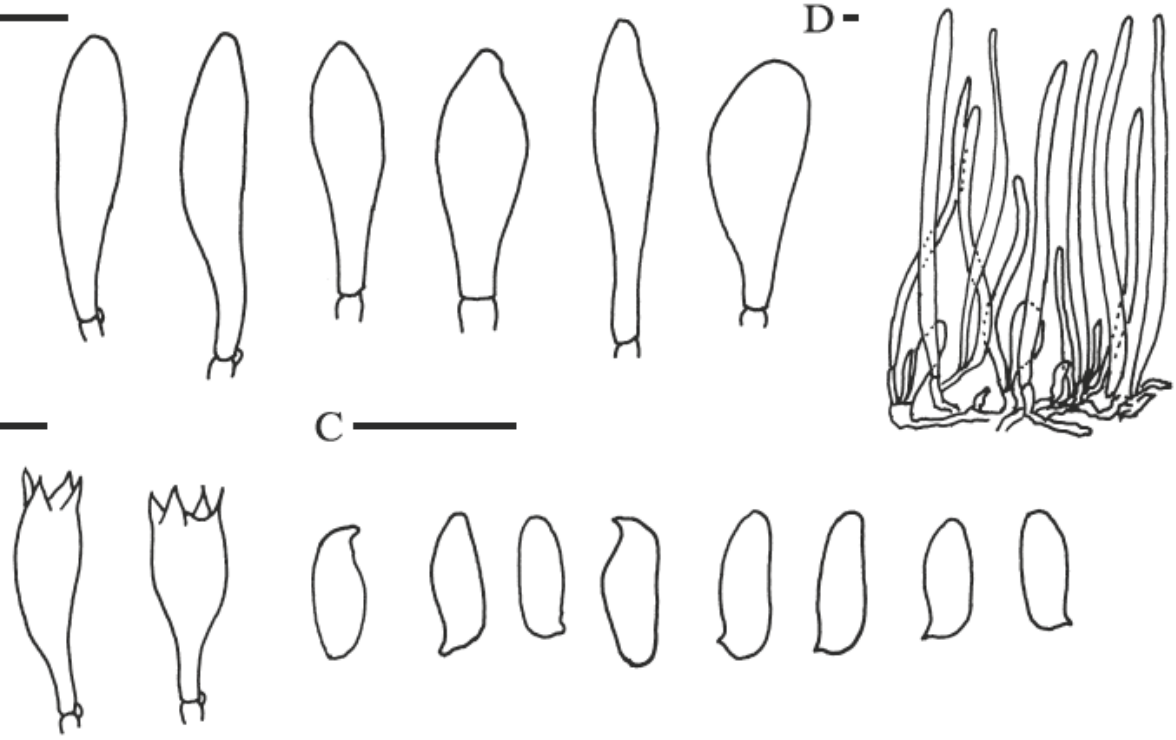

Fig. 9. Lepiota cortinarius var. audreae microcharacters: A - cheilocystidia; B - basidia; $\mathrm{C}-$ spores; $\mathrm{D}$ - pileus covering. Scale bars $=10 \mu \mathrm{m}$. 
Synonyms: Lepiota audreae var. dryadicola (Kühner) M. Bon; Lepiota cortinarius var. dryadicola (Kühner) M. Bon

MACROSCOPIC AND MICROSCOPIC FEATURES: Pileus firstly campanulate, then planoconvex, up to 20-30 mm, dark brown, slightly squamulose-felted in centre, around centre breaking into concentrically arranged, brown patches. Lamellae crowded, cream-coloured. Stipe cylindrical, up to $40 \times 4 \mathrm{~mm}$, covered with sparse brown girdles and squamules on whitish background. Spores Boletus-shape, dextrinoid, 7.0-9.0 $\times$ 3.0-4.0 $\mu \mathrm{m}$ (lit. (6.5)7.0-9.0(10) × (2.5)3.0-3.5(4.0) $\mu \mathrm{m})$. Basidia 4-spored, narrowly clavate, $20-30 \times 6-8 \mu \mathrm{m}$ (lit. 18-29 × 5.5-9 $\mu \mathrm{m}$ ). Lamella edge sterile. Cheilocystidia variable in shape, fusiform, utriform or clavate, $20-40 \times 6-14 \mu \mathrm{m}$ (lit. 15-50 $\times 6-13.5 \mu \mathrm{m})$. Pileus covering composed from long, adnate, ascending and erect hyphae, only rarely septate, with brown pigment, up to $380 \times 20 \mu \mathrm{m}$, short, clavate elements rarely observed between long cells. Clamps present.

Localities: Białowieża Primeval Forest, Białowieża National Park, compartment no. 370, in Tilio-Carpinetum, few basidiocarps on soil, among nitrophilous shrubs; ATPOL: GC-55; 19.09.2009; leg., det. B. Gierczyk; BGF/090919/0015.

Distribution, HABITAT AND REMARKs: Thermophilous species known from Europe, where it was found in Mediterranean to temperate zones, in parks, mine waste heaps as well as deciduous and mixed forest on loamy soil (Vellinga 2001d; Gminder 2003; Kosakyan et al. 2008a), found also in China (Wang 2004). Very rare. Hitherto not mentioned from Poland. The specimens found in Białowieska Primeval Forest produce a more gracile basidiomata than these described by other countries, but the other micro- and macrocharacters remain in accordance with descriptions given in literature. The most important microscopic characters delimiting this species are the Boletus-shape, small spores and pileus covering composed from long, cylindrical elements.

\section{Lepiota cristata var. felinoides Bon}

Description And ICONOGRAPHy: Canduso, Lanzoni (1990): 210 \& 652, Tab. 20b; Kelderman (1994): $82-83$.

\section{SynONYMS: Lepiota subfelinoides Bon \& P.D. Orton}

MACROSCOPIC AND MICROSCOPIC FEATURES: Species microscopically identical with L. cristata but the pileus strongly resembles L. felina - the squamules are radially arranged, darker (dark brown or blackish) and larger than in L. cristata.

LocALITIES: 1. Between Konarzewo village and Podłozice forest ranger’s lodge, a dozen of basidiocarps on rich soil, under nitrophilous shrubs along field road (Prunus spinosa, Crataegus sp., Rosa canina, Rubus sp.); ATPOL: BD-07; 04.09.2010; leg., det. B. Gierczyk; BGF/BF/100904/0003. 2. Białowieża Primeval Forest, Białowieża National Park, compartment no. 371, three basidiocarps on the ground in TilioCarpinetum, among nitrophilous plants; ATPOL: GC-55; 16.09.2009; leg., det. B. Gierczyk; BGF/090916/0019.

DisTRIBUTION, HABITAT AND REMARKS: Taxon of uncertain value, microscopically identical with L. cristata. Some authors recognize it as an ecological form of $L$. cristata, included in its variability (Vellinga 2001d), according to others it is a good variety (Bon 1993) or species - L. subfelinoides Bon \& P.D. Orton (Gminder 2003). Hitherto not mentioned from Poland. The specimens of the L. cristata var.felinoides, 
collected in Białowieska Primeval Forest differ distinctly in their morphology from the fruitbodies of L. cristata var. cristata collected during the same trip in the same habitats.

\section{Lepiota echinella Quél. \& G.E. Bernard var. echinella; E (as L. setulosa)}

DESCRIPTION AND ICONOGRAPHY: Canduso, Lanzoni (1990): 257-258, 285-288 \& 664, Fig. 49 \& 57, Tab. 32b (as L. echinella \& L. setulosa); Kelderman (1994): 108-109, 122-123 (as L. echinella \& L. setulosa); Vellinga (2001d): 125-127, Fig. 90; Gminder (2003): 77-79; Kosakyan et al. (2008a): 366-368, Fig. 7.

LocAlities: 1. Between Myszkowo and Kąsinowo villages, on the roadside of the field road, one basidiocarp in shrubs (Prunus spinosa, Sambucus nigra, Crataegus sp.), under Populus sp. trees; ATPOL: BC-86; 19.09.2010; leg., det. B. Gierczyk; BGF/BG/100919/0006. 2. Between Konarzewo village and Podłozice forest ranger's lodge, very numerous on rich soil, under nitrophilous shrubs along field road (Prunus spinosa, Crataegus sp., Rosa canina, Rubus sp.); ATPOL: BD-07; 04.09.2010; leg., det. B. Gierczyk; BGF/BF/100904/0013. 3. Gołuski village, near the road to Plewiska, two basidiocarps in nitrophilous shrubs (Robinia pseudoacacia, Urtica dioica) at the Scots Pine forest margin; ATPOL: BD-07; 04.09.2010; leg., det. B. Gierczyk; BGF/BF/100904/0018. 4. Otowo near Lusowo village, two basidiocarps on nitrogen-rich soil near the allotments, under Sambucus nigra and Urtica dioica; ATPOL: BD-07; 28.08.2010; leg., det. B. Gierczyk; BGF/ BG/100828/0004. 5. "Uroczysko Marcelin" forest in the W part of Poznań city, two basidiocarps on the ground in the mixed forest (Pinus sylvestris, Padus serotina, Quercus sp.); ATPOL: BD-08; 08.08.2009, 15.08.2010; leg., det. B. Gierczyk; BGF/090808/0001, BGF/BG/100815/0016. 6. Between Chobienice and Kopanica villages, one basidiocarp in nitrophilous shrubs (Robinia pseudoacacia, Crataegus sp., Urtica dioica) along the forest road; ATPOL: BD-31; 11.09.2010; BGF/ BG/100911/0005. 7. Between Błocko and Przemęt villages, in moist, mixed forest (Pinus sylvestris, Quercus sp., Populus sp.), few basidiocarps among Urtica dioica on the roadside of dirt road; ATPOL: BD-34; 11.08.2010; leg., det. B. Gierczyk; BGF/BG/100911/0003. 8. Puszcza Zielonka Landscape Park, a dozen of basidiocarps on rich, moist soil, $1 \mathrm{~km} \mathrm{~S}$ from Łopuchowo village, among Urtica dioica, on the margin of mixed forest; ATPOL: CC-80; 12.09.2010; leg., det. B. Gierczyk; BGF/BG/100912/0018. 9. Białowieża Primeval Forest, Białowieża National Park, compartment no. 370, a dozen of basidiocarps on the ground in Tilio-Carpinetum, among nitrophilous plants; ATPOL: GC-55; 16.09.2009, 19.09.2009; leg., det. B. Gierczyk; BGF/090916/0014, BGF/090919/0016. 10. Białowieża Primeval Forest, Białowieża forest district, compartment no. 525, near Grudki village, two basidiocarps on the ground on the margin of forest road; ATPOL: GC-65; 21.09.2010; leg. A. Kujawa, det. B. Gierczyk; BGF/BF/AK/100921/0006. 11. Kaźmierski Landscape Park, $1.2 \mathrm{~km}$ E from Parchatka village, on the loamy soil, in the wood belonging to Tilio-Carpinetum association, one basidiocarp; ATPOL: FE-13; 05.09.2009; leg. B. Mazurek, det. B. Gierczyk; BGF/BF/090905/0002. 12. Kaczawskie Foothills, 1,5 $\mathrm{km} \mathrm{N}$ from Wleń, Złotoryja forest district, Wleń forest range, compartment no. 30f, few basidiocarps on soil in deciduous forest (Tilia sp., Quercus sp.); ATPOL: AE-59; 30.07.2010, 09.08.2010, 23.08.2010; leg. J. Soboń, det. B. Gierczyk; BGF/ BF/JS/100730/0001, BGF/BF/JS/100809/0001, BGF/BF/JS/100823/0004b. 
Distribution AND REMARKs: Scattered and rare but widespread European species, known also from Asia and North Africa (Wasser 1985; Vellinga 2001d; Gminder 2003; Legon et al. 2005; Kosakyan et al. 2008a). It shows a huge polymorphism - many varieties (sometimes treated as a separated species) were described within this taxon. L. echinella grows mainly in deciduous forests on sandy, nutrient-rich soil. Hitherto it has been mentioned from 12 localities in Poland (Wojewoda 2003; Lisiewska 2006; Nita, Bujakiewicz 2007; Kujawa 2009; Bujakiewicz, Springer 2009).

\section{Lepiota erminea (Fr.) P. Kumm.; V (as L. alba), Ex (as L. erminea)}

Description AND iconography: Canduso, Lanzoni (1990): 163-166, 173-174 \& 645, Fig. 26, Tab. 13a\&b (as L. alba \& L. erminea); Breitenbach, Kränzlin (1995): Vol. 4, Fig. 213 (as L. alba); Vellinga (2001d): 118-119, Fig. 82; Gminder (2003): 66-67 (as L. alba); Kosakyan et al. (2008a): 359-360.

Localities: 1. "Uroczysko Marcelin" forest in the W part of Poznań city, few basidiocarps on the sandy soil on the birch or mixed forests margins, in sunny places; ATPOL: BD-08; 25.07.2009, 25.08.2010, 08.09.2010; leg., det. B. Gierczyk; BGF/090725/0002, BGF/BG/100825/0003, BGF/BG/100908/0010. 2. Nowa Wieś Zbąska village, a dozen of fruitbodies on the roadside, at the margin of Scots Pine forest; ATPOL: BD-21; 11.09.2010; leg., det. B. Gierczyk; BGF/BG/100911/0001. 3. Puszcza Zielonka Landscape Park, Głęboczek village, one basidiocarp on roadside, near cross, on sandy soil under Robinia pseudoacacia; ATPOL: CC-80; 24.08.2010; leg., det. B. Gierczyk; BGF/BG/100824/0001. 4. Puszcza Zielonka Landscape Park, two basidiocarps on roadside, near Łopuchówko forest ranger's lodge, on lawn; ATPOL: CC-80; 12.09.2010; leg., det. B. Gierczyk; BGF/BG/100912/0017. 5. Trójmiejski Landscape Park, Gdańsk city, Słowackiego street, near Matemblewo forest ranger's lodge, two basidiocarps on the overgrown meadow among grasses, on sandy soil; ATPOL: DA-80; 29.08.2004; leg., det. D. Karasiński; BGF/BF/040829/0001. 6. Kaczawskie Foothills, 1.2 km SE from Bełczyna, Złotoryja forest district, Wleń forest range, compartment no. 122i, few basidiocarps on the ground in birch forest; ATPOL: BE-50; 22.09.2010; leg. J. Soboń, det. B. Gierczyk; BGF/BF/JS/100922/0002.

DISTRIBUTION AND REMARKS: In current literature $L$. erminea is considered to be a synonym of L. alba (Bres.) Sacc. It is rather common and widespread in Europe (also in western Asia), known from many countries (Wasser 1985; Vellinga 2001d; Gminder 2003; Legon et al. 2005; Kosakyan et al. 2008a). Found in grasslands on calcareous soil, in thermophilous shrubs and sunny places on forest margins. Hitherto in Poland known from over 10 localities (Wojewoda 2003; Stasińska 2003; Łuszczyński 2007, 2008; Kujawa, Gierczyk 2007; Ślusarczyk 2009, Łuszczyński et al. 2011).

\section{Lepiota felina (Pers.) P. Karst.}

Description AND ICONOGRAPhy: Canduso, Lanzoni (1990): 260-262 \& 660, Fig. 50 \& Tab. 28a; Kelderman (1994): 110-111; Vellinga (2001d): 122-123, Fig. 86; Gminder (2003): 79-80.

Localities: 1. Dezydery Chłapowski Landscape Park, 2 km W from Turew village, young trees clump surrounded by farmlands, one basidiocarp on the rich soil; ATPOL: BD-48; 22.10.2009; leg., det. A. Kujawa; ZBŚRiL 1/22.10.09. 2. Tomaszów Mazowiecki city, Niska street, a dozen of basidiocarps in monastic arboretum, on soil under Ligustrum sp. and Picea sp.; ATPOL: EE-00; 24.10.2006; leg. M. Ciszewski, det. A. Kujawa, B. Gierczyk; BGF/BF/MC/061024/0001. 3. Bieszczady Mts, 
Bieszczady National Park, Górna Solinka valley, one basidiocarp among nitrophilous plants in marshy forest (Alnus incana, Salix sp.), on rich soil; ATPOL: FG-68; 10.10.2009; leg., det. B. Gierczyk; BGF/091010/0001. 4. Białowieża Primeval Forest, Białowieża National Park, compartment no. 131, a dozen of basidiocarps on the nutrient-rich soil in mixed forest, under Picea abies; ATPOL: GC-45; 23.09.2010; leg. A. Kujawa, det. B. Gierczyk; BGF/BF/AK/100923/0001. 5. Kaczawskie Mts, 1 km NE from Tarczyn village, Złotoryja forest district, Wleń forest range, compartment no. 134c, a dozen of basidiocarps on soil in spruce forest; ATPOL: AE-59; 01.10.2010; leg. J. Soboń, det. B. Gierczyk; BGF/BF/JS/101001/0001.

DISTRIBUTION AND REMARKS: Widespread and quite common species of boreosubtropical to boreal distribution, known from Europe, Asia and North America, growing on rich soil in woods (Wasser 1985; Vellinga 2001d; Gminder 2003). Hitherto mentioned from two localities in Poland, from Roztocze and Pieniny National Parks (Wojewoda 2003).

Lepiota forquignonii Quél.

Fig. 10

DESCRIPTION AND ICONOGRAPHY: Canduso, Lanzoni (1990): 263-266 \& 662, Fig. 51, Tab. 30; Kelderman (1994): 112-113; Vellinga (2001d): 124, Fig. 88; Knudsen (2005): 52-54; Kosakyan et al. (2008a): 368-369, Fig. 8; de Albuquerque el al. (2010): 503-506, Fig. 5E-F.

SyNonYMS: Lepiota forquignonii var. coniferarum Bon; Lepiota olivaceobrunnea P.D. Orton; Lepiota forquignonii var. olivaceobrunnea (P.D. Orton) Bon

MACROSCOPIC AND MICROSCOPIC FEATURES: Pileus first hemispherical, then plane, with low umbo, up to $40 \mathrm{~mm}$, covered with minute velvety grey-brown (sometimes with olive tinge) squamules. Stipe up to $60 \mathrm{~mm}$, cylindrical, white, with woolly girdles in lower part and small squamules concolour with that on the pileus. Lamellae free, moderately crowded, white. Spores ellipsoid, 6.0-7.5 × 4.0-4.5 $\mu \mathrm{m}$ (lit. 5.5-8.0 3.5$5.0 \mu \mathrm{m}$ ), dextrinoid. Basidia 4-spored, 15-25 × 4.5-7.0 $\mu \mathrm{m}$ (lit. 16-32 × 3.5-8.0 $\mu \mathrm{m}$ ). Cheilocystidia variable, cylindrical to utriform, sometimes fusiform, 15-30 $\times$ 4.0-9.0 $\mu \mathrm{m}$ (lit. 15-32 $\times$ 3.5-8.0 $\mu \mathrm{m}$ ). Pleurocystidia absent. Pileus covering composed from
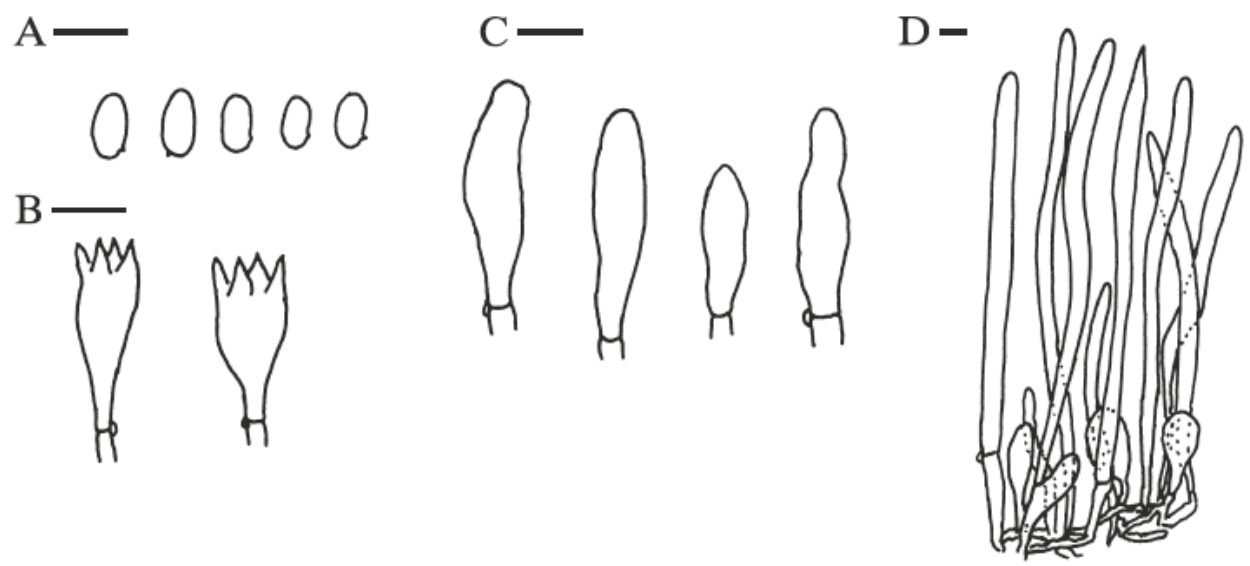

Fig. 10. Lepiota forquignonii microcharacters: A - spores; B - basidia; C - cheilocystidia; $\mathrm{D}$ - pileus covering. Scale bars $=10 \mu \mathrm{m}$. 
up to $350 \mu \mathrm{m}$ long, cylindrical, non-septate elements, intermixed with clavate cells. Clamps present.

Localities: 1. Between Myszkowo and Kąsinowo villages, on the roadside of the field road, a dozen of basidiocarps in shrubs (Prunus spinosa, Sambucus nigra, Crataegus sp.), under Populus sp. threes; ATPOL: BC-86; 19.09.2010; leg., det. B. Gierczyk; BGF/BG/100919/0004. 2. Between Konarzewo village and Podłozice forest ranger's lodge, one basidiocarp on rich soil, under nitrophilous shrubs along field road (Prunus spinosa, Crataegus sp., Rosa canina, Rubus sp.); ATPOL: BD-07; 03.09.2010; leg., det. B. Gierczyk; BGF/BF/100903/0002.

DISTRIBUTION AND REMARKS: Widespread but rather rare in Europe, found mainly in warmer regions, reported from deciduous woods and shrubs, usually on calcareous soil, known also from Asia, Africa, North and South America (Vellinga 2001d; Legon et al. 2005; Kosakyan et al. 2008a). Hitherto not mentioned from Poland. Easy recognized in the field because of olive-grey shades of the pileus. Other Lepiota species with grey, olive or greenish colours belong to section Stenosporae and produce spurred spores.

\section{Lepiota fuscovinacea J.E. Lange \& F.H. Møller}

Description And iconography: Canduso, Lanzoni (1990): 297-300 \& 665, Fig. 60, Tab. 33a; Rald, Heilmann-Clausen (1993): 48, 52-54, Fig. 3 \& 8; Kelderman (1994): 128-129; Breitenbach, Kränzlin (1995): Vol. 4, Fig. 224; Akers, Sundberg (1999): 455-457, Fig. 1; Vellinga (2001d): 129-130, Fig. 94; Gminder (2003): 81-82.

Localities: 1. Kaczawskie Mts, Wojcieszów village near the "Góra Miłek" reserve, one basidiocarp on the calcareous ground on the margin of the beech forest; ATPOL: BE-61; 12.10.2010; leg. T. Pachlewski, det. B. Gierczyk; BGF/BF/ TP/101012/0001. 2. Beskid Mały Mts, "Wapiennik w Inwałdzie" forest, on the calcareous soil, 10 basidiocarps in the marshy forest with Ulmus sp. domination, near the stream; 11.10.2007; ATPOL: DF-85; leg. P. Chachuła, det. B. Gierczyk; BGF/ BF/071011/0002.

DistRIBUTION AND REMARKS: Species not common but widespread in Europe, known from temperate and boreal zones, found also in Asia and North America, growing in deciduous and coniferous forests, on loamy, humus-rich soil (Wasser 1985; Akers, Sundberg 1999; Vellinga 2001d; Gminder 2003; Legon et al. 2005). In Poland known from only three localities, in Tatry Mts, Babia Góra massif and in Dezydery Chłapowski Landscape Park (Wojewoda 2003; Kujawa 2009; Bujakiewicz 2011).

\section{Lepiota griseovirens Maire; E (as L. griseovirens), E (as L. pseudofelina)}

Description AND ICONOGRAPHY: Canduso, Lanzoni (1990): 216-221, 222-225 \& 654, Fig. 40 \& 41, Tab. 22a\&b (as L. griseovirens and L. pseudofelina); Rald et al. (1992): 38; Kelderman (1994): 86-87; Breitenbach, Kränzlin (1995): Vol. 4, Fig. 226; Vellinga (2001d): 135-136, Fig. 101; Tofts (2002): 125, 129-130, 132 \& 135, Fig. 8-9; Gminder (2003): 84; Sysouphanthong et al. (2011): 71-73, Fig. 8.

Localities: 1. Puszcza Zielonka Landscape Park, Dziewicza Góra hamlet near Czerwonak village, few basidiocarps under Robinia pseudoacacia shrubs on sandy, $\mathrm{CaCO}_{3}$-rich soil; ATPOL: BC-99; 02.11.2009, 14.11.2009; leg., det. B. Gierczyk; BGF/091102/0003, BGF/091114/0004. 2. Lusówko village, two basidiocarps on rich soil in Syringa vulgaris shrubs at the slopes near the Lusowskie lake, near yellow 
tourist trail; ATPOL: BC-97; 22.08.2010; leg., det. B. Gierczyk; BGF/BG/100822/0003. 3. Otowo near Lusowo village, one basidiocarp on nitrogen-rich soil near the allotments, under Sambucus nigra and Urtica dioica; ATPOL: BD-07; 28.08.2010; leg., det. B. Gierczyk; BGF/BG/100828/0014.

DistRIBUTION AND REMARKS: Rare but widespread species, known from Europe, Asia, North Africa and South America, growing terrestrial in deciduous woods on sandy, nutrient-rich soil (Wasser 1985; Vellinga 2001d; Gminder 2003; Legon et al. 2005; Kumar, Manimohan 2009a; de Albuquerque el al. 2010; Sysouphanthong et al. 2011). Hitherto known from five localities in Poland (as L. griseovirens and L. pseudofelina; Wojewoda 2003; Bujakiewicz, Stefaniak 2009; Kujawa 2009).

\section{Lepiota ignivolvata Bousset \& Joss.}

Description AND iCONOGRAPHy: Canduso, Lanzoni (1990): 155-158 \& 643, Fig. 24, Tab. 11; Breitenbach, Kränzlin (1995): Vol. 4, Fig. 229; Vellinga (2001d): 122; Gminder (2003): 85-87; Kosakyan et al. (2008a): 360-361, Fig. 3.

Localities: 1. Złoty Potok near Częstochowa, one basidiocarp on the ground, in beech forest; 04.10.2009; ATPOL: DE-96; leg. K. Kołodziejczyk, det. B. Gierczyk; BGF/BF/091004/0001. 2. Olsztyn near Częstochowa, one basidiocarp on the ground, in beech forest; ATPOL: DE-94; 26.09.2009; leg. K. Kołodziejczyk, det. B. Gierczyk; BGF/BF/090926/0002. 3. Rudniański Landscape Park, 2 km W from Przeginia Duchowna village, few basidiocarps on the $\mathrm{CaCO}_{3}$-rich soil in the beech forest; ATPOL: DF-77; 21.10.2004; leg., det. D. Karasiński; BGF/BF/041021/0001.

DistRIBUTION AND REMARKS: Widespread and quite common species, known from Mediterranean to temperate zones of Europe and Asia, found in many countries, preferring beech-forests on calcareous soil (Vellinga 2001d; Gminder 2003; Legon et al. 2005; Kosakyan et al. 2008a). In Poland mentioned from one locality (Wojewoda 2003).

\section{Lepiota lilacea Bres., Ex}

Description And iconography: Canduso, Lanzoni (1990): 308-312 \& 668, Fig. 63, Tab. 36; Rald, Heilmann-Clausen (1993): 48, 50-53, Fig. 2 \& 6; Vellinga (2001d): 140-141, Fig. 108; Gminder (2003): 87-89; de Albuquerque el al. (2010): 503-504, Fig. 4; Vellinga (2010): 668-669, Fig. 3.

LocALities: 1. Lusówko village, few basidiocarps on rich soil in Syringa vulgaris shrubs at the slopes near the Lusowskie lake, near yellow tourist trail; ATPOL: BC-97; 28.08.2010; leg., det. B. Gierczyk; BGF/BG/100828/0009. 2. Between Konarzewo village and Podłozice forest ranger's lodge, very numerous on rich soil, under nitrophilous shrubs along field road (Prunus spinosa, Crataegus sp., Rosa canina, Rubus sp.); ATPOL: BD-07; 03.09.2010, 04.09.2010; leg., det. B. Gierczyk; $\mathrm{BGF} / \mathrm{BF} / 100903 / 0001, \mathrm{BGF} / \mathrm{BF} / 100904 / 0001$. 3. "Uroczysko Marcelin" forest in the W part of Poznań city, two basidiocarps on the nitrogen-rich soil in the Robinia pseudoacacia shrubs; ATPOL: BD-08; 25.07.2009, 21.08.2010; leg., det. B. Gierczyk; BGF/090725/0003, BGF/BG/100821/0001. 4. Ciechanów, allotments at the Opinogórska street, in the unheated greenhouse with the Lycopersicon esculentum plantation, few basidiocarps on the ground; EC-44; 25.10.2009; leg. A. Szczepkowski, det. B. Gierczyk; BGF/BF/091025/0001. 
Distribution And Remarks: Species known from Europe, Asia, South \& North America and Africa, occurring in tropical and temperate zones (Wasser 1985; Vellinga 2001d; Gminder 2003; Legon et al. 2005; Kosakyan et al. 2008a; de Albuquerque el al. 2010). Not common but widespread, found in many countries, on rich soil in woods and parks. From the territory of Poland mentioned only twice, on 1933 from Elbląg and from Dezydery Chłapowski Landscape Park (Wojewoda 2003; Kujawa 2009).

\section{Lepiota ochraceofulva P.D. Orton}

DESCRIPTION AND ICONOGRAPHY: Canduso, Lanzoni (1990): 312-314 \& 665, Tab. 33b; Rald, HeilmannClausen (1993): 48-50, Fig. 1 \& 4; Vellinga (2001d): 141-142, Fig. 109; Hausknecht, Pidlich-Aigener (2005): 67-68, 71, Fig. 12a-c.

LocalitiEs: 1. Between Myszkowo and Kąsinowo villages, on the roadside of the field road, hundreds of basidiocarps in shrubs (Prunus spinosa, Sambucus nigra, Crataegus sp.), under Populus sp. threes; ATPOL: BC-86; 19.09.2010; leg., det. B. Gierczyk; BGF/BG/100919/0001. 2. Krajenka village, one basidiocarp in alder forest; ATPOL: CE-37; 09.06.2010; leg. P. Zawada, det. A. Kujawa, B. Gierczyk; BGF/BF/ PZ/100609/0001. 3. Dezydery Chłapowski Landscape Park, trees clump surrounded by farmlands near Turew (the so-called "Cmentarzysko"), under deciduous trees (Aesculus hypocastanum, Fraxinus sp, Syringa vulgaris, Symphoricarpos albus), on rich soil; ATPOL: BD-37; 28.08.2008; leg., det. A. Kujawa; ZBŚRiL 19/28.08.2008.

DistRIBUTION AND REMARKs: Rare and widespread species, known from many South and Central European countries, occurring mainly in Fagus and other deciduous woods, on humus-rich, loamy soil (Vellinga 2001d; Hausknecht, Pidlich-Aigener 2005; Legon et al. 2005). In Poland found on one locality, in Świętokrzyskie Mts (Wojewoda 2003).

\section{Lepiota oreadiformis Velen.}

Description AND ICONOGRAPHY: Canduso, Lanzoni (1990): 243 \& 657, Tab. 25b; Kelderman (1994): 64-65; Breitenbach, Kränzlin (1995): Vol. 4, Fig. 232; Vellinga (2001d): 129, Fig. 93; Gminder (2003): 92-93; Kosakyan et al. (2008a): 360-362, Fig. 4.

Localities: 1. Near the Widawka river, at the foot of Góra Kamieńsk hill, $1.5 \mathrm{~km}$ $\mathrm{N}$ from Huta Brudzka village, a few basidiocarps on the sandy soil on the meadow; ATPOL: DE-35; 26.07.2008; leg. J. Nowicki, det. B. Gierczyk; BGF/BF/080726/0001. 2. $1.3 \mathrm{~km}$ SE from Waglin village, on rich soil under Syringa vulgaris, on the desolate farm; ATPOL: DE-47; 07.08.2010; leg. J. Nowicki, det. B. Gierczyk; BGF/BF/ JN/100807/0001. 3. Bieszczady Mts, Bieszczady National Park, near the road between Wyżna Pass and Berehy Górne village, on the ground in dry meadow; ATPOL: FG-68; 29.06.2009; leg., det. B. Gierczyk; ZBŚRiL 15/BG/BdPN/26.06.09, BGF/090629/0004.

Distribution AND REMARKs: Species known from Europe and Asia, growing in Mediterranean to boreal zones (Wasser 1985; Vellinga 2001d; Gminder 2003; Legon et al. 2005; Kosakyan et al. 2008a). Rather rare but widespread, occurring in various habitats: at roadsides, in meadows, pastures and woods - mainly on sandy or loamy soils. Hitherto recorded on three localities in Poland - from "Nowa Wieś" reserve, Roztocze National Park and Gorce Mts (Wojewoda 2003). 


\section{Lepiota parvannulata (Lasch) Gillet; Ex}

DesCRIPTION AND ICONOGRAPHY: Canduso, Lanzoni (1990): 178-181 \& 648, Fig. 31, Tab. 16a; Kelderman (1994): 102-103; Vellinga (2001d): 119-120, Fig. 83; Gminder (2003): 91-92 Knudsen (2005): 50-52.

Localities: Lusówko village, few basidiocarps on rich soil in Syringa vulgaris shrubs at the slopes near the Lusowskie lake, near yellow tourist trail; ATPOL: BC-97; 26.07.2009, 22.08.2010, 28.08.2010; leg., det. B. Gierczyk; BGF/090726/0007, BGF/BG/100822/0005, BGF/BG/100828/0007.

DisTRIBUTION AND REMARKs: Species occurring in Mediterranean to boreal zones, known from Europe and Asia (Wasser 1985; Vellinga 2001d; Gminder 2003; Legon et al. 2005). Very rare. In Poland mentioned from three localities on the turn of the $19^{\text {th }}$ century, in the vicinities of Wrocław, Świecie and Międzyrzec Podlaski (Wojewoda 2003). It was found on nutrient-rich soils, in woods - mainly on warm, sunexposed slopes.

\section{Lepiota pseudolilacea Huijsman}

DESCRIPTION AND ICONOGRAPHY: Canduso, Lanzoni (1990): 274-279, 660 \& 661, Fig. 54 \& 55, Tab. 28b \& 29 (as L. pseudohelveola var. pseudohelveola \& L. pseudohelveola var. sabulosa); Kelderman (1994): 116-121 (as L. pseudohelveola var. pseudohelveola, L. pseudohelveola var. sabulosa \& L. pseudolilacea); Vellinga (2001d): 123-124, Fig. 87; Gminder (2003): 94-95 (as L. pseudohelveola \& L. pseudolilacina).

Localities: 1. Kaczawskie Mts, $0.5 \mathrm{~km}$ SW from Bystrzyca village, Złotoryja forest district, Wleń forest range, compartment no. 134z, one basidiocarp on the ground, at deciduous forest margin (Quercus sp., Betula sp., Alnus sp.); ATPOL: AE-59; 06.11.2009; leg. J. Soboń, det. B. Gierczyk; BGF/BF/091106/0001. 2. Puszcza Notecka forest, Obrzycko village, $0.8 \mathrm{~km} \mathrm{~W}$ from the Obrzycko-Zamek hamlet, one basidiocarp on the rich soil, at the margin of mixed wood, among Urtica dioica; ATPOL: BC-66; 06.11.2009; leg., det. B. Gierczyk; BGF/091106/0002. 3. "Uroczysko Marcelin" forest in the W part of Poznan city, on the ground in mixed wood, common in the whole area; ATPOL: BD-08; 24.10.2009, 25.10.2009, 31.10.2009, 06.11.2009; leg., det. B. Gierczyk; BGF/091024/0001, BGF/091024/0003, BGF/091025/0022, BGF/091025/0023, BGF/091025/0024, BGF/BGF/091031/0011, BGF/091031/0012, BGF/091106/0002. 4. Puszcza Zielonka Landscape Park, Łopuchówko forest district, compartment no. 50, $0.4 \mathrm{~km}$ SE from the Łopuchówko forest ranger's lodge, two basidiocarps in the mixed forest (Pinus sylvestris, Betula pendula, Quercus sp., Alnus glutinosa), on the ground; ATPOL: CC-80; 13.09.2008; leg., det. B. Gierczyk; BGF/080913/0006. 5. Rudniański Landscape Park, 2 km W from Przeginia Duchowna village, two basidiocarps on the ground in the beech forest, on $\mathrm{CaCO}_{3}$-rich soil; ATPOL: DF-77; 21.10.2004; leg., det. D. Karasiński; BGF/BF/041021/0002. 6. Białowieża Primeval Forest, Białowieża National Park, compartment no. 371, few basidiocarps on the nutrient-rich soil in Tilio-Carpinetum, among Urtica dioica; ATPOL: GC-55; 16.09.2009; leg., det. B. Gierczyk; BGF/090916/0019.

DistRIBUTION AND REMARKs: Species growing in Mediterranean and temperate regions of Europe and Asia, widespread and not rare, occurring in grasslands and woods (Vellinga 2001d; Gminder 2003; Legon et al. 2005). Hitherto reported only from four localities in Poland - from Cedyński Landscape Park, Tynieckie Hills, "Jelonka" and "Łężczok" reserves (Halama, Panek 2000; Wojewoda 2003, Kałucka 2009). 
Lepiota rubella Bres.

Fig. 11

Description AND ICONOGRAPHY: Canduso, Lanzoni (1990): 314-315 \& 667, Tab. 35c; Breitenbach, Kränzlin (1995): Vol. 4, Fig. 215 (as L. aff. bettinae); Vellinga et al. (1998): 275-276, Fig. 1; Vellinga (2001d): 129; Gminder (2003): 95.

Synonyms: Lepiota bettinae Dörfelt; Echinoderma bettinae (Dörfelt) Bon

MACROSCOPIC AND MICROSCOPIC FEATURES: Pileus small, up to $10 \mathrm{~mm}$, firstly rounded-conical, then flat, with small, indistinct umbo, covered with a small, dense, hairy, purplish squamules on white background. Lamellae crowded, free, whitish to yellowish. Stipe 8-15 $1 \mathrm{~mm}$, white at the apex, pinkish to brown at the base, with purplish flocks and minute scales. Smell of bruised fruitbodies strong, of a coal-gas, similar to that of Cystolepiota bucknallii (according to literature acid spermatic). Spores 3.5-5.0 × 2.5-3.5 $\mu \mathrm{m}$ (lit. 3.5-5.0 $\times$ 2.5-3.0 $\mu \mathrm{m}$ ), oblong, basidia 4-spored. Lamellar edge sterile, cheilocystidia 15-20 5.0-6.0 $\mu \mathrm{m}$ (lit. 15-22 × 5.0-6.5 $\mu \mathrm{m}$ ), clavate, pleurocystidia absent. Pileus covering composed from thick-walled (walls up to $2 \mu \mathrm{m}$ thick), 5.5-7 $\mu \mathrm{m}$ (lit. 5-7 $\mu \mathrm{m}$ ) wide, purple-brown hyphae, terminal elements clavate. Clamps present in all tissues.

LoCALITIES: Poznań, city palm house, gregariously in big groups on the fragments of strongly decayed wood and rich soil in the greenhouse with tropical plants; ATPOL: BD-08; 06.12.2009, 08.02.2010, 14.02.2010; leg., det. B. Gierczyk; BGF/091206/0002, BGF/100208/0003, BGF/100214/0003.

DistRIBUTION, HABITAT AND REMARKs: Species described from Botanical Garden in Berlin, native to South America and Caribbean islands. In Europe rarely found in botanical gardens and greenhouses (Belgium, Denmark, Italy, Germany, Great Britain, Netherlands, Turkey) (Vellinga et al. 1998; Vellinga 2001d; Gminder 2003;
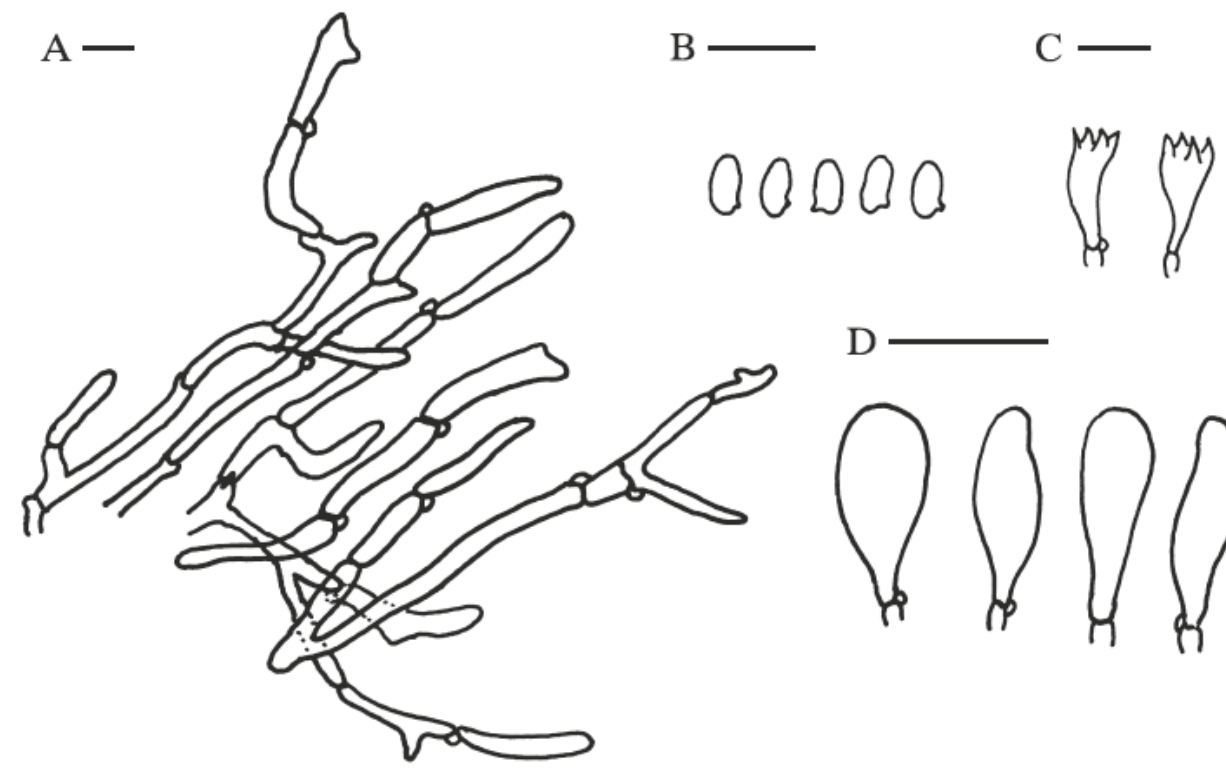

$\mathrm{D}$
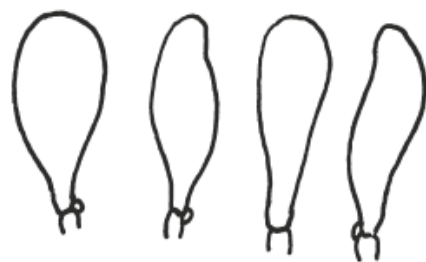

Fig. 11. Lepiota nubella microcharacters: A - pileus covering; B - spores; C - basidia; $\mathrm{D}$ - cheilocystidia. Scale bars $=10 \mu \mathrm{m}$. 
Işiloğlu et al. 2010). Not mentioned from Poland. Small basidiocarps, characteristic, strong smell, thick-walled, brown, diverticulate hyphae of pileus covering and minute spores make this species easy to recognize.

\section{Lepiota subalba Kühner ex P.D. Orton}

DESCRIPTION AND ICONOGRAPHY: Canduso, Lanzoni (1990): 229-230; Kelderman (1994): 96-97; Vellinga (2001d): 133-134, Fig. 98; Tofts (2002): 125, 132 \& 135, Fig. 4-5; Gminder (2003): 95-96.

Localities: 1. "Uroczysko Marcelin” forest in western part of Poznań city, a dozen of basidiocarps on the ground in the mixed forest (Pinus sylvestris, Padus serotina, Quercus sp.); ATPOL: BD-08; 15.08.2010; leg., det. B. Gierczyk; BGF/100815/0021. 2. Poznań city, two basidiocarps on the roadside of the wood patch in the deciduous forest (Tilia sp, Quercus sp.), the part of the "Malta" recreational complex; ATPOL: BD-09; 24.08.2010; leg., det. B. Gierczyk; BGF/100824/0004.

DisTRIBUTION AND REMARKS: Known from many European countries in temperate zone, growing on rich soil in mixed and coniferous woods (Wasser 1985; Vellinga 2001d; Gminder 2003; Legon et al. 2005). Mentioned also from Asia (Wasser 1985). In Poland found on three localities: Słowiński National Park, Lubelszczyzna and Świętokrzyskie Mts (Wojewoda 2003; Flisińska 2004; Łuszczyński 2007, 2008).

\section{Lepiota subincarnata J.E. Lange var. subincarnata}

DESCRIPTION AND ICONOGRAPHY: Canduso, Lanzoni (1990): 244-247 \& 657, Fig 46 \& Tab. 25a; Rald et al. (1992): 39; Kelderman (1994): 104-105; Vellinga (2001d): 127-128, Fig. 92; Gminder (2003): 97-99; de Albuquerque el al. (2010): 506-507, Fig. 6.

Localities: 1. Between Myszkowo and Kąsinowo villages, on the roadside of the field road, two basidiocarps in shrubs (Prunus spinosa, Sambucus nigra, Crataegus sp.), under Populus sp. threes; ATPOL: BC-86; 19.09.2010; leg., det. B. Gierczyk; BGF/BG/100919/0002. 2. Between Konarzewo village and Podłozice forest ranger's lodge, very numerous on rich soil, under nitrophilous shrubs along field road (Prunus spinosa, Crataegus sp., Rosa canina, Rubus sp.); ATPOL: BD-07; 04.09.2010; leg., det. B. Gierczyk; BGF/BF/100904/0006, BGF/BF/100904/0012. 3. "Uroczysko Marcelin” forest in western part of Poznań city, near Junikowski Stream, at the margin of the mixed forest (Pinus sylvestris, Quercus sp., Acer campestre), two basidiocarps on wet, rich soil, under Padus sp. and Crataegus sp.; ATPOL: BD-08; 08.09.2010; leg., det. B. Gierczyk; BGF/BF/100908/0002. 4. Between Chobienice and Kopanica villages, few basidiocarps in nitrophilous shrubs (Robinia pseudoacacia, Crataegus sp., Urtica dioica) along the forest road; ATPOL: BD-31; 11.09.2010; leg., det. B. Gierczyk; BGF/ BG/100911/0006. 5. Between Błocko and Przemęt villages, in moist, mixed forest (Pinus sylvestris, Quercus sp., Populus sp.), few basidiocarps among Urtica dioica on the roadside of dirt road; ATPOL: BD-34; 11.08.2010; leg., det. B. Gierczyk; BGF/ BG/100911/0002. 6. 0,5 km S from Łopuchowo village, on the roadside, a few basidiocarps on soil in Prunus spinosa shrubs; ATPOL: CC-80; 12.09.2010; leg., det. B. Gierczyk; BGF/BG/100912/0001. 7. Puszcza Zielonka Landscape Park, a dozen of basidiocarps on rich, moist soil, $1 \mathrm{~km} \mathrm{~S}$ from Łopuchowo village, among Urtica dioica, on the margin of mixed forest; ATPOL: CC-80; 12.09.2010; leg., det. B. Gierczyk; BGF/BG/100912/0002. 8. Warsaw city, Skaryszewski Park, few basidiocarps on the ground, under Picea sitchensis and Thuja sp., ATPOL: ED-27; 12.09.2010; 
leg. A. Szczepkowski, det. B. Gierczyk; BGF/BF/ASz/100912/0001, BGF/BF/ ASz/100912/0002, BGF/BF/ASz/100912/0004. 9. Sękocin, park of Forest Research Institute, one basidiocarp on soil, under Picea pungens, ATPOL: ED-35; 05.07.2010; leg. A. Szczepkowski, det. B. Gierczyk; BGF/BF/ASz/100705/0001.

Distribution AND REMARKs: Widespread in Europe, known also from Asia, South and North America, growing in gardens, parks, deciduous and mixed forests and mine waste heaps, on rich soil (Wasser 1985; Vellinga 2001d; Gminder 2003; Legon et al. 2005; Kosakyan et al. 2008a; Kumar, Manimohan 2009a; de Albuquerque et al. 2010). In Poland found only few times (Wojewoda 2003; Kujawa 2009; Kujawa, Gierczyk in press).

\section{Lepiota ventriosospora D.A. Reid var. ventriosospora}

DESCRIPTION AND ICONOGRAPHY: Canduso, Lanzoni (1990): 188-192 \& 647, Fig 34 \& Tab. 17; Kelderman (1994): 68-69; Breitenbach, Kränzlin (1995): Vol. 4, Fig. 235; Vellinga (2001d): 117-118, Fig. 81 (as L. magnispora); Gminder (2003): 89-90 (as L. magnispora); Pearson (2007): 67, Fig. 2.

Localities: 1. "Uroczysko Marcelin" forest in the W part of Poznań city, many subpopulations scattered on the whole area, on the ground in deciduous and mixed woods; ATPOL: BD-08; 18.10.2008, 25.10.2008, 17.09.2009, 31.10.2009; leg., det. B. Gierczyk; BGF/081018/0009, BGF/081025/0004, BGF/090917/0004, BGF/091031/0004, BGF/091031/0005. 2. Kaszubski Landscape Park, near Kartuzy village, one basidiocarp on the ground in the beech forest, on rich soil; ATPOL: CA-87; 30.08.2004; leg., det. D. Karasiński; BGF/BF/040830/0001. 3. Kaszubski Landscape Park, near Przewóz village, one basidiocarp on soil in spruce forest; ATPOL: CA-96; 25.07.2004; leg. D. Karasiński, det. B. Gierczyk; BGF/BF/040725/0001. 4. Kaszubski Landscape Park, near Ręboszewo village, few basidiocarps on the ground in the spruce forest; ATPOL: CA-97; 05.08.2004; leg. D. Karasiński, det. B. Gierczyk; BGF/BF/040805/0001. 5. Puszcza Zielonka Landscape Park, Łopuchówko forest district, compartment no. $50,0.4 \mathrm{~km}$ SE from the Łopuchówko forest ranger's lodge, two basidiocarps on soil, in mixed wood (Pinus sylvestris, Quercus sp.), at the margin of alder forest; ATPOL: CC80; 13.09.2008; leg. B. Gierczyk, M. Wójtowski, det. B. Gierczyk; BGF/080913/0004. 6. Kłomnice near Częstochowa, one basidiocarp on the ground, in mixed forest (Quercus sp., Pinus sylvestris, Betula sp.); ATPOL: DE-75; 15.08.2009; leg. K. Kołodziejczyk, det. B. Gierczyk; BGF/BF/090815/0001. 7. Krzeszowice near Kraków, in the "Zwierzyniec" forest, two basidiocarps on the ground; ATPOL: DF-57; 13.10.2004; leg. D. Karasiński, det. B. Gierczyk; BGF/BF/041013/0001. 8. Mogilany village, two basidiocarps in the oak-hornbeam forest; ATPOL: DF-79; 14.10.2004; leg. D. Karasiński, det. B. Gierczyk; BGF/BF/041014/0001. 9. Warsaw city, "Rezerwat Króla Jana Sobieskiego" reserve, two basidiocarps in forest belonging to Tilio-Carpinetum association; ATPOL: ED-27; 02.09.2010; leg. A. Szczepkowski, det. B. Gierczyk; BGF/BF/ASz/100902/0001. 10. Near Regut village, Celestynów forest district, Celestynów forest range, two basidiocarps on soil, in Scots pine forest with admixing of deciduous trees, near forest road; ATPOL: ED-49; 04.09.2010; leg. A. Szczepkowski, det. B. Gierczyk; BGF/BF/ ASz/100904/0001. 11. Białowieża Primeval Forest, Hajnówka forest district, compartment no. 598, a few basidiocarps on the ground in the mixed forest; ATPOL: GC-64; 17.09.2009; leg., det. B. Gierczyk; BGF/090917/0004. 12. Białowieska Primeval Forest, Hajnówka forest district, compartment no. 632, near Topiło village, one basidiocarps 
on the ground on the margin of the mixed forest, on forest road; ATPOL: GC-64; 22.09.2010; leg. A. Kujawa, det. B. Gierczyk; BGF/BF/AK/100922/0001. 13. Białowieża Primeval Forest, Białowieża forest district, compartment no. 498, near Grudki village, at the roadside of Krzemieniecka Droga road, one basidiocarp on the ground on the margin of the mixed forest (Pinus sylvestris, Betula pendula, Corylus avellana); ATPOL: GC-65; 23.09.2010; leg. A. Szczepkowski, det. B. Gierczyk; BGF/BF/ASz/100923/0002. 14. $1 \mathrm{~km}$ NE from Tuczna village, one basidiocarp on the roadside of the field road to Choroszczynka, under Prunus sp. and Populus sp.; ATPOL: GD-53; 00.08.2007; leg. T. Pachlewski, det. B. Gierczyk; BGF/BF/TP/070800/0001. 15. Kaczawskie Foothills, $1.5 \mathrm{~km}$ SE from Bełczyna village, Złotoryja forest district, Wleń forest range, compartment no. 123t, few basidiocarps on soil in deciduous forest (Carpinus betulus, Quercus sp., Populus tremula); ATPOL: BE-50; 10.08.2010; leg. J. Soboń, det. B. Gierczyk; BGF/BF/JS/100810/0003. 16. Kaczawskie Mts, $1.1 \mathrm{~km}$ E from Tarczyn village, Złotoryja forest district, Wleń forest range, compartment no. 133f, few basidiocarps on soil in mixed forest (Pinus sylvestris, Quercus sp., Betula pendula); ATPOL: BE-50; 20.08.2010; leg. J. Soboń, det. B. Gierczyk; BGF/BF/JS/100820/0002. 17. Kaczawskie Foothills, $2 \mathrm{~km} \mathrm{~N}$ from Wleń village, Złotoryja forest district, Wleń forest range, compartment no. 30b, few basidiocarps on soil in deciduous forest (Carpinus betulus, Quercus sp., Ulmus sp.); ATPOL: AE-59; 26.08.2010; leg. J. Soboń, det. B. Gierczyk; $\mathrm{BGF} / \mathrm{BF} / \mathrm{JS} / 100826 / 0001 \mathrm{a}$.

Distribution, HABITAT AND REMARKs: Widespread in Europe, Asia, Africa, rather common. Saprotrophic and terrestrial, growing in woods on rich soil (Wasser 1985; Vellinga 2001d; Gminder 2003; Legon 2005). Although this species was mentioned also from North America, molecular studies of the American specimens suggest that they may represent other taxon (Vellinga 2000, 2001g). In Poland hitherto known from about ten localities (Lawrynowicz et al. 2002; Adamczyk 2003; Wojewoda 2003, Bujakiewicz 2004, Łuszczyński 2007, 2008; Gierczyk et al. 2009; Kałucka 2009; Kujawa 2009; Halama, Romański 2010; Kujawa, Gierczyk in press). Probably often misidentified as L. clypeolaria.

\section{Leucoagaricus (Locq.) Singer}

From over 25 Leucoagaricus species, occurring in neighbour countries (20 in Germany, 15 in Nordic Countries, 13 in Slovakia and 11 in Czech Republic) (Gminder 2003; Škubla 2003; Zelený 2006; Lange 2008e) only five (L. americanus, L. badhamii, L. cretaceus, L. melanotrichus and L. serenus) were hitherto recorded in Poland (Wojewoda 2003; Lisiewska 2004; Kujawa 2009; Wojewoda, Karasiński 2010).

\section{Leucoagaricus americanus (Peck) Vellinga}

DesCRIPTION AND ICONOGRAPHY: Canduso, Lanzoni (1990): 415-419 \& 680, Fig. $91 \&$ Tab. 48 (as $L$. bresadolae var. bresadolae); Breitenbach, Kränzlin (1995): Vol. 4, Fig. 238 (as L. bresadolae); Vellinga (2000): 433-436, Fig. 5; Vellinga (2001c): 92-94, Fig. 60.

LocALITIEs: Ogrodniczki village, near the fence of the sawmill, a dozen of basidiocarps on sawdust; ATPOL: GC-20; 29.09.2010; leg. M. Gryc, det. B. Gierczyk; BGF/ $\mathrm{BF} / \mathrm{MG} / 100929 / 0001$.

DiSTRIBUTION AND REMARKS: Species of unknown, probably tropical origin. Known from all over the Europe, except its northern part (Vellinga 2001c; Legon et al. 2005; 
Lange 2008e; Wojewoda, Karasiński 2010). Rather rare. Known also from North America and Asia (Wasser 1985; Vellinga 2000). Found on sawdust and woodchips, but also on nutrient-rich soil and compost heaps, in clusters. In older literature the name $L$. bresadolae is used for European collections. Further morphological and molecular investigations confirm the identity of $L$. bresadolae and L. americanus (Vellinga 2001c). In Poland found only once, in Kraków at a supermarket parking (Wojewoda, Karasiński 2010).

Leucoagaricus cinerascens (Quél.) Bon \& Boiffard

Fig. 12

Description AND ICONOGRAPHy: Canduso, Lanzoni (1990): 422-424 \& 682, Fig. 93 \& Tab. 50.

SyNONYMS: Lepiota cinerescens Quél.

MACROSCOPIC AND MICROSCOPIC FEATURES: Basidiocarps medium-size, pileus up to $12 \mathrm{~cm}$, hemispheric at first, then plane, covered with dark grey to blackish fibrillose squamules on greyish or ocher background. Stipe up to $9 \times 1.5 \mathrm{~cm}$, cylindrical, with slightly bulbous base, whitish and glabrous. Annulus ascending, white. Lamellae distant, white to pale pinkish. Spores 8.0-10.0 × 5.0-6.0 um (lit. 7.5-11.0 $\times$ 4.8-6.0 $\mu \mathrm{m}$; Canduso, Lanzoni (1990)), ovoid to ellipsoid, dextrinoid, metachromatic, germ-pore with plug. Basidia 4-spored, 30-35 × 8.0-10.0 $\mu \mathrm{m}$ (lit. 27-35 $\times$ 8-10 $\mu \mathrm{m}$; Canduso, Lanzoni (1990)). Lamellar edge sterile, cheilocystidia 35-45 × 8-11 um (lit. 35-50 $\times$ 8-12 $\mu \mathrm{m}$; Canduso, Lanzoni (1990)), fusiform to clavate, irregular, sometime with excrescence. Pleurocystidia absent. Pileus covering composed from globose to widecylindrical elements giving rise to long, slender cylindrical hyphae. Clamps absent.
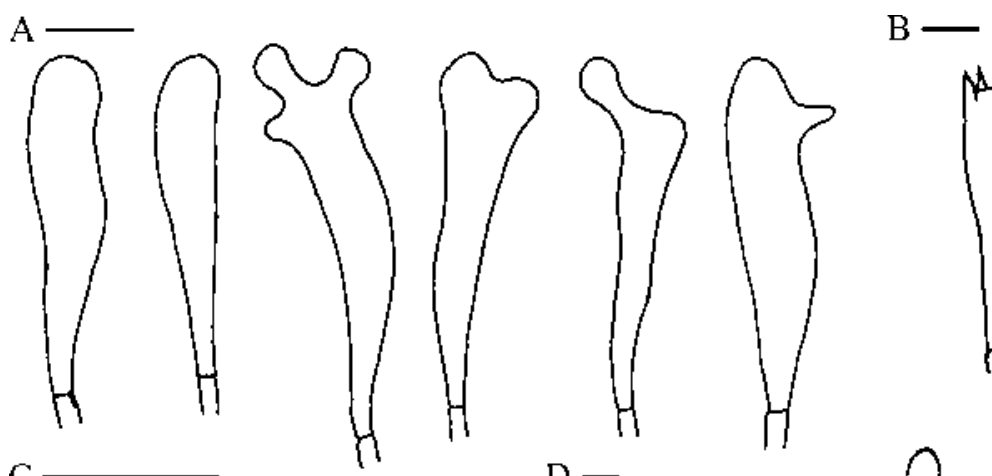

$\mathrm{C}$
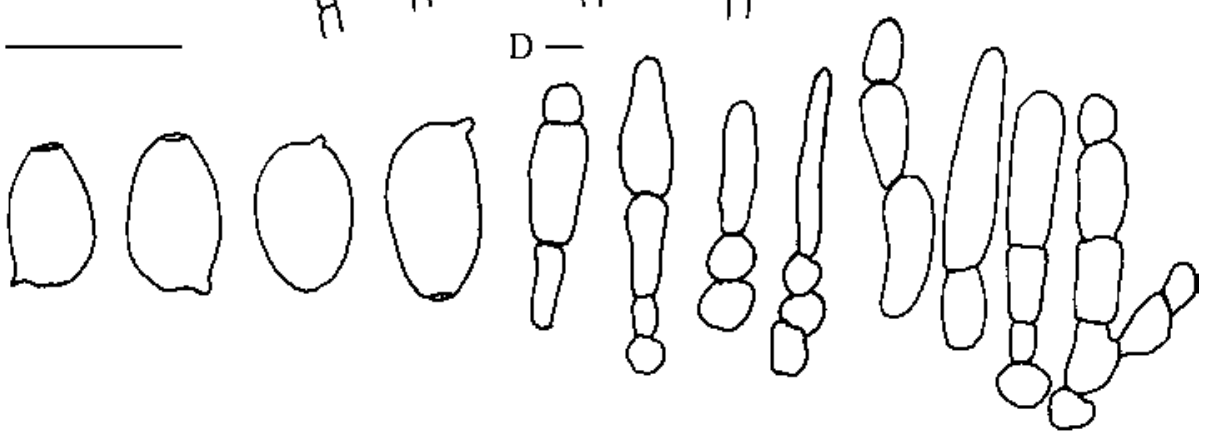

Fig. 12. Leucoagaricus cinerescens microcharacters: A - cheilocystidia; B - basidia; C - spores; $\mathrm{D}-$ pileus covering. Scale bars $=10 \mu \mathrm{m}$. 
LOCALITIES: Near Ruda village (powiat radomszczański county), one basidiocarp among grasses on the roadside, about $0.1 \mathrm{~km}$ from the mixed-forest margin; ATPOL: DE-66; 30.08.2008; leg. K. Kołodziejczyk, det. B. Gierczyk; BGF/BF/ KK/080830/0001.

DISTRIBUTION AND REMARKS: Very rare species, known only from warmer regions of Europe. The name $L$. cinerascens is often used for the grey or brown variety of $L$. leucothites, but here we follow after the concept of Canduso and Lanzoni (1990) and Bon (1993) and use this name for the species with wide-cylindrical rising to slender cylindrical elements of pileus covering. Hitherto not mentioned from Poland. In the field recognized by stout basidiocarps and grey appressed squamules on the pileus. The unique structure of pileus covering makes this species difficult to mistake with others of these genus.

Leucoagaricus ionidicolor Bellù \& Lanzoni

Fig. 13

DESCRIPTION AND ICONOGRAPHY: Canduso, Lanzoni (1990): 335-338 \& 670, Fig. 67 \& Tab. 38b; Henrici (2000a): 75-76; Vellinga (2001c): 99, Fig. 67; Holec (2009): 329-335, Fig. 1.

Synonyms: Leucocoprinus caeruleoviolaceus D.A. Reid; Leucoagaricus caeruleoviolaceus (D.A. Reid) Bon; Leucoagaricus ionidicolor var. caeruleoviolaceus (D.A. Reid) D.A. Reid

MACROSCOPIC AND MICROSCOPIC FEATURES: Pileus up to $50 \mathrm{~mm}$, hemispheric when young, then applanate, without umbo. Surface of pileus white with densely, radially arranged small, dark purplish to violaceous-purplish fibrils. Lamellae moderately crowded, free, white to pale cream. Stipe up to $45 \times 5 \mathrm{~mm}$, whitish, covered with purple fibrils. Annulus ascending, disappearing, with tomentose, white upper side and purplish underside. Spore print white. Spores 6.0-7.0 × 3.5-4.5 $\mu \mathrm{m}$ (lit. 6.0-7.0 $\times$ $3.5-4.5 \mu \mathrm{m}$ ), ellipsoid to oblong, with rounded or somewhat acute apex, dextrinoid,

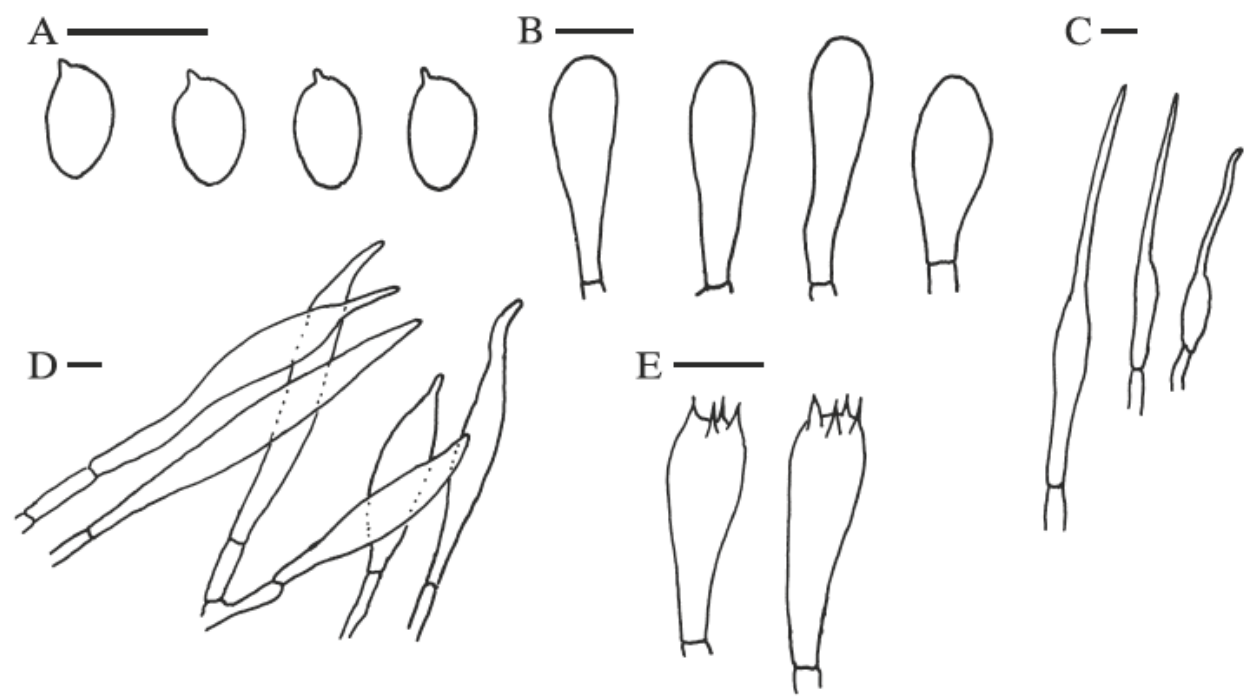

Fig. 13. Leucoagaricus ionidicolor microcharacters: A - spores; B - cheilocystidia; C - terminal elements of caulipelis; D - pileus covering; $\mathrm{E}$ - basidia. Scale bars $=10 \mu \mathrm{m}$. 
without germ-pore. Basidia 4-spored, 15-22 5.0-7.0 $\mu \mathrm{m}$ (lit. 14-21 $\times$ 5.5-6.5 $\mu \mathrm{m}$ ). Lamella edge sterile, cheilocystidia 20-42 7-11 $\mu \mathrm{m}$ (lit. 23-40 × 8-10 $\mu \mathrm{m}$ ), clavate, irregular. Pleurocystidia absent. Pileus covering composed from adnate to ascending, long tapering elements, widest in basal part. Stipitipellis a cutis, with terminal elements with long and thin excrescence. Clamps absent.

Localities: Białowieska Primeval Forest, Białowieża National Park, compartment no. 399A, in Tilio-Carpinetum, two basidiocarps on rich soil; ATPOL: GC-55; 16.09.2009; leg., det. B. Gierczyk; BGF/090916/00018.

DisTRIBUTION, HABITAT AND REMARKS: Very rare species, known throughout Europe. Saprotrophic, growing terrestrial on clayey soil (Vellinga 2001c; Legon et al. 2005; Holec 2009). Hitherto not found in Poland. The purple-red granules on pileus and stipe, ellipsoid spores and long, tapering elements of pileus covering differentiate it clearly from other species of genus Leucoagaricus.

\section{Leucoagaricus sericifer (Locq.) Vellinga f. sericatellus (Malençon.) Vellinga \\ Fig. 14}

DeSCRIPTION AND ICONOGRAPHY: Canduso, Lanzoni (1990): 451-452 \& 687, Tab. 55d; Kelderman (1994): 146-147 (as L. sericellatus); Henrici (2000b): 111 (as L. sericatula); Vellinga (2001c): 104-105, Fig. 74; Gminder (2003): 137-138 (as Sericeomyces sericifer).

SYNONYMS: Lepiota sericatella Malençon; Leucoagaricus sericatellus (Malençon) Bon; Sericeomyces sericatellus (Malençon) Bon; Sericeomyces sericatus var. sericatellus (Malençon) Heinem.

MACROSCOPIC AND MICROSCOPIC FEATURES: Pileus up to $45 \mathrm{~mm}$, firstly blunt conical, then flat, with small, indistinct umbo, white to pale yellowish in centre, tending to become pinkish with age. Pileus surface shining, radially satiny fibrillose, sometimes
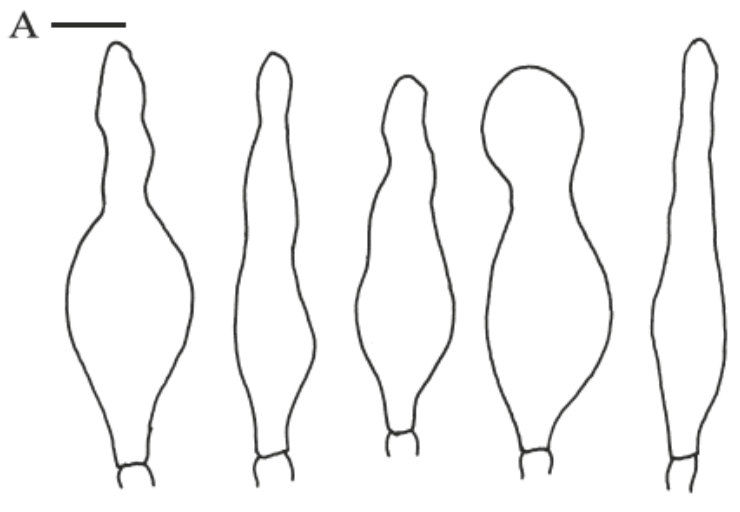

$\mathrm{B} \longrightarrow$

C

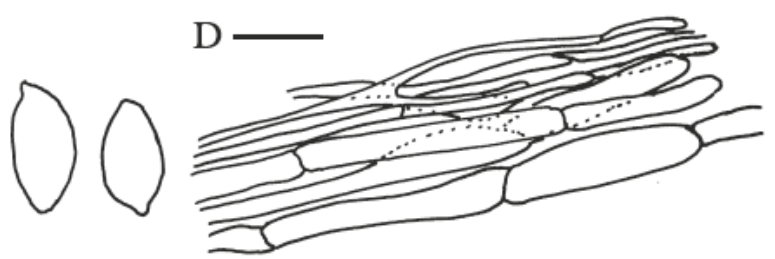

Fig. 14. Leucoagaricus sericifer var. sericellatus microcharacters: A - cheilocystidia; B - basidia; $\mathrm{C}-$ spores; $\mathrm{D}$ - pileus covering. Scale bars $=10 \mu \mathrm{m}$. 
with indistinct squamules. Lamellae crowded, free, at first pale cream or white, then pinkish or yellowish-brown. Stipe $20-90 \times 2-4 \mathrm{~mm}$, whitish, becoming pinkish or brownish after touch or with age, indistinctly pruinose or glabrous. Annulus present (rarely absent), evanescent, with a cuff around the stipe, whitish. Spore print white. Spores 8.0-12.0 × 4.0-5.5 $\mu \mathrm{m}$ (lit. 8.0-12.5 × 4.0-5.5 $\mu \mathrm{m}$; in var. sericifer $6.0-10.0 \times$ 3.0-5.0 $\mu \mathrm{m})$, oblong to cylindrical, slightly amygdaliform, dextrinoid. Basidia 16-35 $\times$ 6-10 $\mu \mathrm{m}$ (lit. 15-34 × 6-9.5 $\mu \mathrm{m}$ ), 2-spored (4-spored in var. sericifer). Cheilocystidia arranged in tufts, very variable in shape and size, 19-100 $\times 10-23 \mu \mathrm{m}$ (lit. 17-90 $\times 6-22 \mu \mathrm{m})$, lageniform, clavate or irregular. Pleurocystidia absent. Pileipellis and stipitipellis a cutis. Clamps absent.

LocALITIEs: 1. Lusówko village, few basidiocarps on rich soil in Syringa vulgaris shrubs at the slopes near the Lusowskie lake, near yellow tourist trail; ATPOL: BC97; 28.08.2010; leg., det. B. Gierczyk; BGF/BG/100828/0006. 2. "Uroczysko Marcelin" forest, W part of the Poznań city, near the Junikowski stream, in ruderalized, mixed forest (Pinus sylvestris, Quercus robur, Tilia cordata, Carpinus betulus, Crataegus sp., Sambucus nigra, Padus serotina), two basidiocarps on rich soil; ATPOL: BD-08; 11.10.2008; leg., det. B. Gierczyk; BGF/081011/0001, ZBŚRiL 1/BG/111008. 3. Białowieża Primeval Forest, Białowieża National Park, compartment no. 370 and $371 \mathrm{C}$, in Tilio-Carpinetum, a dozen of basidiocarps on rich soil, singly; ATPOL: GC-55; 16.09.2009, 19.09.2009; leg., det. B. Gierczyk; BGF/090916/0021, BGF/090919/0006.

Distribution, HABITAT AND REMARKs: Rare but widespread European species, known from many countries, with a centre of distribution in Mediterranean and temperate zones, found also in North Africa (Vellinga 2001c; Gminder 2003). Saprotrophic, growing on sandy, loamy or clayey soil in deciduous woods. Hitherto not mentioned from Poland. Macroscopically similar to some white Lepiota species. Easy to recognize because of the shape of cystidia and 2-spored basidia.

\section{Leucocoprinus Pat.}

Most of the species belonging to this genus of tropical origin, introduced to Europe, occurring mainly indoors, in greenhouses and buildings, in pots with tropical plants. Some of them spread outside in temperate regions. From Poland four Leucocoprinus species were hitherto mentioned (Wojewoda 2003; Wojewoda, Karasiński 2010), from Germany - 6, Nordic Countries, Czech Republic and Slovakia - 5 species (Gminder 2003; Škubla 2003; Zelený 2006; Lange 2008f).

\section{Leucocoprinus cepistipes (Sowerby) Pat.}

Description And iconography: Canduso, Lanzoni (1990): 472-475 \& 691, Fig. 104 \& Tab. 59; Breitenbach, Kränzlin (1995): Vol. 4, Fig. 246; Vellinga (2001a): 77-78, Fig. 50; Gminder (2003): 112-113; Rother, de Silveira (2009): 724-725, Fig. 11-15.

Localities: Gdańsk city, Potokowa street, communal dump of the horticultural waste, about twenty basidiocarps on wood-chips; ATPOL: DA-80; 25.08.2008; leg. M. Wantoch-Rekowski, det. B. Gierczyk; BGF/BF/MWR/080825/0001.

DisTRIBUTION AND REMARKS: Species of tropical origin, introduced to Europe with plants, naturalized now and apparently increasing, known from many countries but everywhere rare, found on humus-rich soil, woodchips, compost or manure, in greenhouses 
and outside (Vellinga 2001a; Gminder 2003; Legon et al. 2005). Known also from Asia, Africa and South and North America (Wasser 1985; Rother, de Silveira 2009). In Poland found only five time, in greenhouses in Kraków, Przemyśl, Warsaw and Wrocław cities, and in private apartment in Kraków (Wojewoda 2003; Wojewoda, Karasiński 2010).

\section{Macrolepiota Singer}

Because of different species conception presented by various authors the number of species occurring in Europe is difficult to establish - 7 species according to Lange (2008g), 30 according to Bon (1993). In Polish literature 9 taxa are mentioned (Wojewoda 2003; Kujawa 2011).

\section{Macrolepiota excoriata (Schaeff.) Wasser var. excoriata}

DESCRIPTION AND ICONOGRAPHY: Canduso, Lanzoni (1990): 572-576 \& 708, Fig. 129 \& Tab. 76; Vellinga (2001a): 70-71, Fig. 47; Gminder (2003): 121-123; Lange, Vellinga (2004): 33.

Localities: 1. Puszcza Notecka Forest, Obrzycko village, $0,2 \mathrm{~km}$ W from the Obrzycko-Zamek hamlet, near the dirt road, under Robinia pseudoacacia threes at the margin of the field; ATPOL: BC-66; 06.11.2009; leg., det. B. Gierczyk; BGF/091106/0003. 2. Wielkopolski National Park, on the roadside of the dirt road between Trzebaw and Jarosławiec villages, one basidiocarp in nitrophilous shrubs, under Robinia pseudoacacia; ATPOL: BD-17; 10.08.2010; leg., det. B. Gierczyk; BGF/BG/100810/0003.

Distribution, HABITAT AND REMARKS: Very variable and cosmopolitan species, within several varieties of an uncertain value was described, known from Europe, Asia, Australia, Africa and Americas, occurring mainly on roadsides and nutrientpoor grasslands (Vellinga 2001a; Gminder 2003). Hitherto mentioned from about a dozen localities or so in Poland, but a lot of them are historical (Lawrynowicz et al. 2002; Wojewoda 2003, 2005; Szczepkowski et al. 2008; Ślusarczyk 2009).

Macrolepiota heimii (Locq.) Bon

Fig. 15

Description AND ICONOGRAPHY: Canduso, Lanzoni (1990): 549-552 \& 704, Fig. 122 \& Tab. 72; Breitenbach, Kränzlin (1995): Vol. 4, Fig. 249.

Synonyms: Leucocoprinus heimii Locq.; Leucocoprinus naucinus Locq.

MACROSCOPIC AND MICROSCOPIC FEATURES: Pileus first hemispheric, then planoconvex with umbo, up to $80 \mathrm{~mm}$, white or whitish, glabrous or with discrete granular and flocculose squamules, concolour with background. Lamellae moderate crowded, white to pale cream-coloured. Stipe white, cylindrical with distinctly bulbous base, up to $100 \times 11 \mathrm{~mm}$. Annulus white, thin and simple, hanging. Spores elliptical, slightly amygdaliform, thick-walled, with germ pore covered with hyaline cap, dextrinoid and metachromatic, 12.0-15.0 × 8.0-9.5 $\mu \mathrm{m}$ (lit. 12.0-16.6 × 7.9-9.5 $\mu \mathrm{m}$; Breitenbach, Kränzlin (1995)). Basidia utriform, 4-spored, 38-47 × 15-20 um (lit. 35-45 × 15-18 $\mu \mathrm{m}$; Breitenbach, Kränzlin (1995)), with basal clamp. Cheilocystidia narrowly utriform, clavate or flexuous cylindrical, colourless, 25-40 × 12-16 $\mu \mathrm{m}$ (lit. 25-42 × 10-15 $\mu \mathrm{m}$; Breitenbach, Kränzlin (1995)). Pleurocystidia absent. Cap covering built up from septate, cylindrical elements, lying on pileus surface, up to $140 \times 10 \mu \mathrm{m}$. The basidiomata of M. heimii are very similar to that of Leucoagaricus leucothites. 


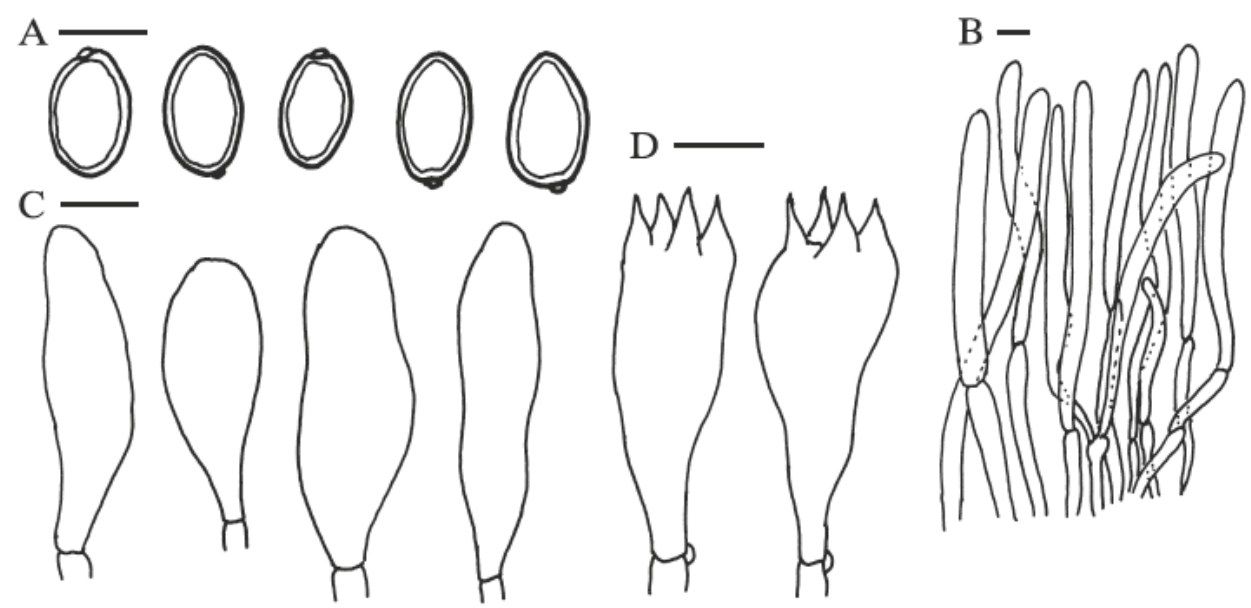

Fig. 15. Macrolepiota heimii microcharacters: A - spores; B - pileus covering; C - cheilocystidia; D - basidia. Scale bars $=10 \mu \mathrm{m}$.

LoCALITIES: Wyżyna Małopolska Upland, "Krzyżanowice” reserve, ca. $11 \mathrm{~km}$ W of Busko Zdrój, a dozen of basidiomata in xerothermic grassland, on the calcareous soil; ATPOL: EF-24; 20.09.2007; leg. M. Piątek, det. B. Gierczyk; KRAM F-48045.

DistriBution, HABITAT AND REMARKS: According to Vellinga (2001a) this species is identical with $M$. excoriata, but the others (e.g.: Hausknecht, Pidlich-Aigener 2004) recognize it as a separate species. Distinct macroscopical and ecological differences between them suggest that these species are not conspecific. It is rather rare but widespread, thermophilous fungus, occurring in xerothermic grasslands (Canduso, Lanzoni 1990; Breitenbach, Kränzlin 1995). Hitherto not mentioned from Poland. Because of glabrous, white pileus easy to mistaken with Leucoagaricus leucothites. It differs from the former by larger spores and basidia as well as presence of the clamps in the hymenium.

\section{Macrolepiota konradii (P.D. Orton) M.M. Moser}

DESCRIPTION AND ICONOGRAPHY: Canduso, Lanzoni (1990): 584-588 \& 711, Fig. 132 \& Tab. 79; Gminder (2003): 129-130 (as M. procera var. konradii); Kosakyan et al. (2008b): 69-70, Fig. 5.

Localities: Puszcza Zielonka Landscape Park, Łopuchowo forest district, compartment no. 83, $0.9 \mathrm{~km}$ E from Annowo forest ranger's lodge, four basidiocarps on the calcareous soil in mixed forest (Pinus sylvestris, Corylus avellana, Quercus sp.); ATPOL: BC-99; 02.11.2009; leg., det. B. Gierczyk; BGF/091102/0004.

DISTRIBUTION, HABITAT AND REMARKS: Species of uncertain status - according to Vellinga (2001a) it is an ecological form of M. mastoidea, however other authors (e.g., Canduso, Lanzoni 1990) recognize it as a "good" species or a variety of $M$. procera (e.g., Gminder 2003). It is known from Europe and Asia where it grows in forests on calcareous soil (Wasser 1985; Gminder 2003; Kosakyan et al. 2008b). Hitherto mentioned from three localities in Poland - Tynieckie Hills, Pieniny National Park and Wigry National Park (Wojewoda 2003 ; Halama, Romański 2010). 


\section{Macrolepiota nympharum (Kalchbr.) Wasser}

Description AND ICONOGRAPHY: Canduso, Lanzoni (1990): 525-530 \& 698, Fig. 117, 118 \& Tab. 66 (as M. puellaris); Breitenbach, Kränzlin (1995): Vol. 4, Fig. 255 (as M. puellaris); Vellinga (2001c): 91-92, Fig. 59 (as Leucoagaricus nympharum); Gminder (2003): 125-126; Lange, Vellinga (2004): 41; Kibby (2007): 39-40 (as Leucoagaricus nympharum).

Localities: 1. Near Ogrodniczki village, Puszcza Knyszyńska forest; ATPOL: GC-20; 12.09.2010; leg. M. Gryc, det. B. Gierczyk; BGF/BF/MG/100912/0001. 2. Kaczawskie Foothills, 2.1-3 km N from Wleń village, Złotoryja forest district, Wleń forest range, compartment no. 221 and 22r, few basidiocarps on soil in mixed forest (Pinus sylvestris, Quercus sp., Betula pendula, Larix sp.); ATPOL: AE-59; 16.08.2010, 17.08.2010; leg. J. Soboń, det. B. Gierczyk; BGF/BF/JS/100816/0001, BGF/BF/ $\mathrm{JS} / 100817 / 0001$.

Distribution, HABITAT AND REMARKs: Widespread but rare European species, known from many countries, where was found in Picea (or other coniferous) forests or, rarely in deciduous ones (Vellinga 2001c; Gminder 2003). Known also from Asia (Wasser 1985). It grows on poor, sandy soil. Until now in Poland known from seven localities (Wojewoda 2003; Bujakiewicz, Kujawa 2010; Narkiewicz 2011).

\section{Macrolepiota procera (Scop.) Singer f. permixta (Barla) Vizzini \& Contu}

Description And iconography: Canduso, Lanzoni (1990): 514-517 \& 696, Fig. 114 \& Tab. 64 (as M. procera var. fuliginosa); Breitenbach, Kränzlin (1995): Vol. 4, Fig. 253; Vellinga (2001a): 67; Gminder (2003): 130-131 (as M. procera var. permixta); Vizzini et al. (2011): 160, Fig. 5 b.

Localities: 1. Kaczawskie Plateau, $1.5 \mathrm{~km} \mathrm{~S}$ from Sobota village, a few basidiocarps on the ground, in the pasture with brushwood formed by deciduous trees (Quercus sp., Alnus sp., Betula sp., Salix sp.); ATPOL: AE-49; 13.11.2009, 02.11.2010; leg. J. Soboń, det. B. Gierczyk; BGF/BF/091113/0001, BGF/BF/JS/101102/0001. 2. Puszcza Zielonka Landscape Park, Łopuchowo forest district, compartment no. 71, $0.3 \mathrm{~km}$ SE from Annowo forest ranger's lodge, few basidiocarps on the calcareous soil in mixed forest (Pinus sylvestris, Quercus sp.); ATPOL: BC-99; 02.11.2009; leg. B. Gierczyk, M. Zalas, det. B. Gierczyk; BGF/091102/0005. 3. Kaczawskie Plateau, $2 \mathrm{~km}$ SE from the Bełczyna village, Złotoryja forest district, Wleń forest range, compartment no. 125i, one basidiocarp on the ground in deciduous forest (Fagus sylvatica, Quercus sp.); BE-50; 19.11.2009; leg. J. Soboń, det. B. Gierczyk; BGF/ BF/091119/0001.

DistRIBUTION, HABITAT AND REMARKS: Widespread European taxon, growing in sunny places in woods and parks on humus-rich soil (Vellinga 2001a; Gminder 2003). Rarely reported, probably not distinguished from M. procera s. str. According to some authors (e.g., Vellinga 2001a, Lange 2008g) it is a "good" species $-M$. permixta (Barla) Pacioni, while others (e.g., Gminder 2003) recognize it as a variety of M. procera (M. procera var. permixta (Barla) Quadr. \& Langhini). The current molecular studies by Vizzini et al. (2011) show that it is nearly identical with $M$. procera so they reduce it to a morphological form. The main characters of $M$. permixta, which differ it from the $M$. procera, are darker, red-brown squamules and the reddening of the context. From Poland mentioned only once, from Czechy Orlańskie reserve (Kałucka 2009). 


\section{Macrolepiota rhacodes (Vittad.) Singer var. bohemica (Wichanský) Bellù \& Lanzoni}

DESCRIPTION AND ICONOGRAPHY: Canduso, Lanzoni (1990): 536-542 \& 701, Fig. 120 \& Tab. 69; Gminder (2003): 133-134; Vellinga (2003a): 364-365, Fig. 3 (as Chlorophyllum brunneum); Vellinga (2003b): 260-263, Fig. 1-2; Lange, Vellinga (2004): 37 \& 39, Fig. 3 (as Chlorophyllum brunneum); Vellinga (2008): 3-5 (as Chlorophyllum brunneum); Kibby, Henrici (2011): 90-91 \& 93, Fig. 2-5 \& 8a,d (as Chlorophyllum brunneum).

Localities: 1. On the roadside between Osiek and Wławie, on the margin of the field, under Tilia sp.; ATPOL: BD-47; 11.09.2010; leg., det. B. Gierczyk; BGF/ BG/100911/0002. 2. Near Nieledwia village, few basidiocarps on soil, in mixed forest with predomination of coniferous trees, under Abies alba; ATPOL: DG-23; 19.09.2010; leg., det. R. Taran; BGF/BF/RT/100919/0001.

DistRIBUTION AND REMARKS: The typical variety of this species is very common and widely distributed. Also $M$. rhacodes var. bohemica is known from many European countries, but it is mentioned in the literature much less frequent. It grows on rich and manure soil and on compost, mainly in human-impacted habitats: in gardens and parks, on roadsides and in hothouses (Vellinga 2001a; Gminder 2003). Known also from Australia (Vellinga 2003). By some authors it is recognized as conspecific with $M$. rhacodes var. rhacodes (e.g.: Vellinga 2001a), while the others regarded it as a "good" species (e.g.: Lange 2008a) or M. rhacodes variety (e.g.: Gminder 2003). Often placed in genus Chlorophyllum (Vellinga 2003; Lange 2008a). The main characters differentiating these taxa are the shape and dimensions of the cheilocystidia and the form of the ring. Hitherto recorded on two localities in Poland (Wojewoda 2003), but it is probably not distinguished from the nominative variety.

\section{Macrolepiota rhodosperma (P.D. Orton) Migl. var. rhodosperma}

Fig. 16

DESCRIPTION AND ICONOGRAPHY: Breitenbach, Kränzlin (1995): Vol. 4, Fig. 250 (as M. konradii); Vellinga (2001a): 67-68, Fig. 45 (as M. fuliginosa); Gminder (2003): 129 (as M. procera var. fuliginosa).

Synonyms: Macrolepiota procera var. fuliginosa sensu Vellinga; Macrolepiota fuliginosa sensu Vellinga; Lepiota rhodosperma P.D. Orton

MACROSCOPIC AND MICROSCOPIC FEATURES: Pileus large, up to $200 \mathrm{~mm}$, at first spherical or conical, then plane with indistinct umbo, covered with grey brown to dark grey brown star-shaped calotte and easy removable squamules with a recurved edges; background radially fibrillose or floccose, paler than velar patches. Lamellae firstly creamcoloured, then cream-beige, free. Stipe up to $250 \times 15 \mathrm{~mm}$, cylindrical with clavate base, covered with grey-brown, irregular bands. Annulus thick, with double crown. Context of stipe and pileus not changing or becoming yellow-brown when exposed to air. Spores ellipsoid or oblong, indistinctly amygdaliform, thick-walled, with apical germ pore covered by hyaline cap, dextrinoid, 11.5-19.0 × 8.0-11.0 $\mu \mathrm{m}$ (lit. (11.5)12.0$20.0 \times 7.5-11.5 \mu \mathrm{m}$ ). Basidia 4-spored (rarely 2-spored), broadly clavate, $32-51 \times 11$ $15 \mu \mathrm{m}$ (lit. 30-52 $\times 10-16 \mu \mathrm{m}$ ), clamped. Cheilocystidia variable in shape, cylindrical, utriform, clavate, lageniform, often catenate, 22-60 × 9-16 $\mu \mathrm{m}(16-60 \times 7-17 \mu \mathrm{m})$. Pleurocystidia absent. Trichodermal covering of pileus composed from erect, elongate, cylindrical, septate elements with brown pigment. The basidiocarps of M. rhodosperma var. rhodosperma are similar to that of the M. procera $\mathrm{s}$. str.

Localities: 1. Kaczawskie Plateau, $2.5 \mathrm{~km} \mathrm{~N}$ from Wleń, Złotoryja forest district, Wleń forest range, compartment no. 25a, one basidiocarp at the margin of 


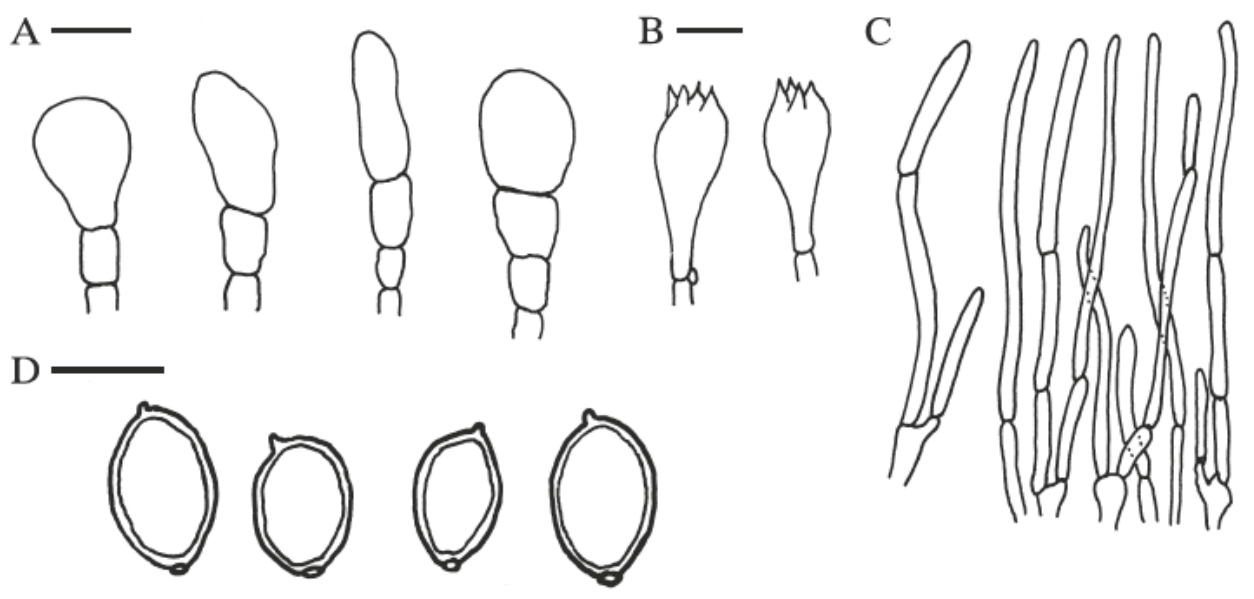

Fig. 16. Macrolepiota rhodosperma var. rhodosperma microcharacters: A - cheilocystidia; $\mathrm{B}$ - basidia; $\mathrm{C}$ - pileus covering; D - spores. Scale bars $=10 \mu \mathrm{m}$.

deciduous forest; ATPOL: AE-59; 17.11.2009; leg. J. Soboń, det. B. Gierczyk; BGF/ $\mathrm{BF} / 091117 / 0001$. 2. On the south from the Ujazdówek village, one basidiocarp on the ground in the mixed forest (Abies alba, Carpinus betulus); ATPOL: DE-57; 19.10.2008; leg. J. Nowicki, det. B. Gierczyk; BGF/BF/081019/0001. 3. Kaczawskie Foothills, $1.2 \mathrm{~km} \mathrm{SE}$ from Bełczyna village, Złotoryja forest district, Wleń forest range, compartment no. $122 \mathrm{~d}$, few basidiocarps on the ground in spruce forest; ATPOL: BE-50; 28.07.2010; leg. J. Soboń, det. B. Gierczyk; BGF/BF/JS/100728/0001.

DISTRIBUTION, HABITAT AND REMARKS: Widespread but rarely mentioned species, probably not distinguished from $M$. procera $\mathrm{s}$. str. Growing in woods and on roadsides, usually on loamy, rich soil. According to Vizzini et al. (2011) M. fuliginosa (Barla) Bon (= M. procera var. fuliginosa (Barla) Bellú \& Lanzoni) described from Mediterranean France is a taxon very close to $M$. procera, occurring predominantly Mediterranean, preferring xerophilous habitats. The ITS sequence analysis shows it is only a forma of $M$. procera (M. procera f. fuliginosa (Barla) Vizzini \& Contu). The agaric of $M$. procera habit, with thick walled elements in pileus covering, forming grey-brown, easily removable patches ( $M$. fuliginosa sensu Vellinga) is a different taxon. The ITS sequence and morphological analysis shows it is conspecific with M. rhodosperma var. rhodosperma (P.D. Orton) Migl. (see Vizzini et al. 2001 for details). It is known from Denmark southwards to Spain (Vellinga 2001a; Lange 2008f; Vizzini et al. 2011). Hitherto not mentioned from Poland.

\section{Macrolepiota venenata Bon}

Fig. 17

DESCRIPTION AND ICONOGRAPHY: Canduso, Lanzoni (1990): 542-544 \& 702, Tab. 70; Vellinga (2001a): 73; Gminder (2003): 134-135 (as M. rhacodes var. venenata); Vellinga (2003b): 266-267, Fig. 6.

MACROSCOPIC AND MICROSCOPIC FEATURES: Pileus up to $160 \mathrm{~mm}$, first subspherical, then plane, without umbo, with central, brown calotte and brown squamules on pale background, radially arranged flocci and small squamules present in the outer part of cap. Lamellae crowded, white to cream-coloured. Stipe up to $150 \times 15 \mathrm{~mm}$, with bulbous base, glabrous, pale. Ring simple, hanging. Flesh white, discolouring orange when 

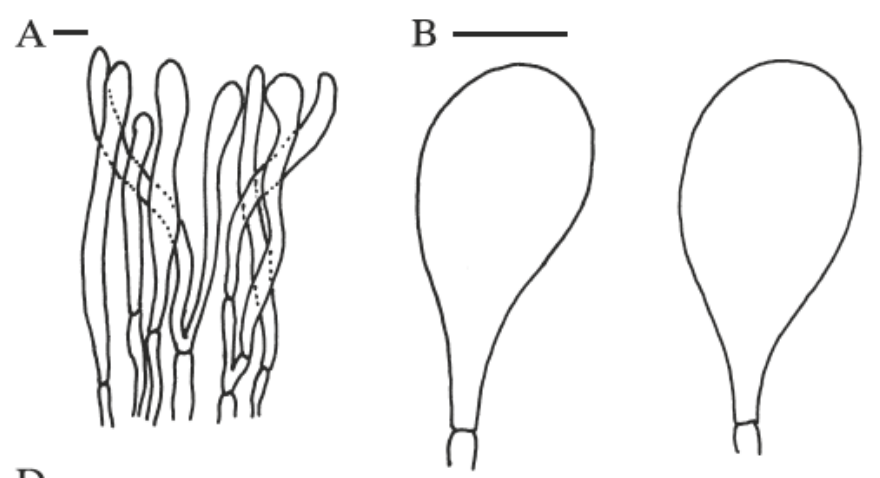

$\mathrm{C}$
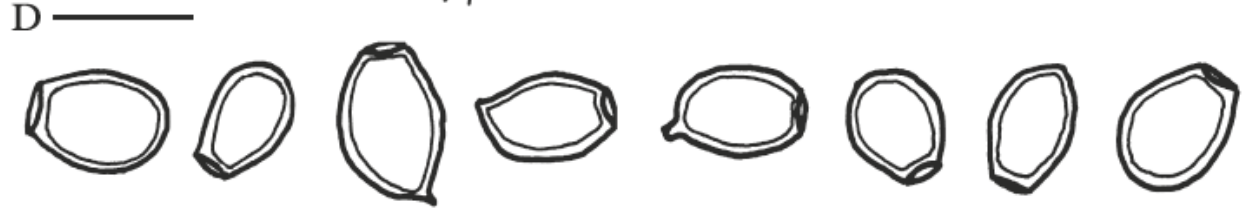

Fig. 17. Macrolepiota venenata microcharacters: A - pileus covering; B - cheilocystidia; C basidia; D - spores. Scale bars $=10 \mu \mathrm{m}$.

bruised. Spores ellipsoid to amygdaliform, distinctly truncate, with wide germ pore, thickwalled, dextrinoid, 9.5-11.0 × 6.5-8.2 $\mu \mathrm{m}$ (lit. 9.5-11.5 × 6.5-8.0 $\mu \mathrm{m}$ ). Basidia 4-spored, broadly clavate, $30-40 \times 10-15 \mu \mathrm{m}$ (lit. 27-38 × 11-15 $\mu \mathrm{m}$ ). Cheilocystidia clavate, 25-38 $\times 10-16 \mu \mathrm{m}$ (lit. 26-35 $\times 11-15 \mu \mathrm{m})$. Trichodermal velum on pileus composed from cylindrical to narrowly ellipsoid hyphae, with clavate terminal elements. Clamps absent.

LOCALITIES: Wójcik village near Gomunice, one basidiocarp on the ground in the deciduous riverside shrubs; ATPOL: DE-46; 20.09.2009; leg. J. Nowicki, det. B. Gierczyk; BGF/BF/090920/0003.

DISTRIBUTION, HABITAT AND REMARKS: Rare but probably undercollected in Europe, known from Germany, Italy, France and Spain, found mainly in nitrogen-rich grasslands, but also in thermophilous forests margins (Vellinga 2001a; Gminder 2003). Probably not distinguished from $M$. rhacodes var. bohemica from which it differs in the spores shape, clamps absence, annulus structure and the presence of radial structures on pileus. Toxic. Hitherto not mentioned from Poland.

\section{Melanophyllum Velen.}

Two Melanophyllum species were mentioned from Europe, both were found in Poland, one (M. haematospermum) is quite common.

Melanophyllum eyrei (Massee) Singer, E

DESCRIPTION AND ICONOGRAPHY: Canduso, Lanzoni (1990): 69-72 \& 633, Fig. 5 \& Tab. 1b; Kelderman (1994): 24-25; Ludwig (2000): 107, Tab. 105:49.1; Ludwig (2001): 390; Vellinga (2001f): 162, Fig. 128; Kasuya, Knudsen (2003): 328-329, Fig. 3 \& 4.

LoCALITIES: Białowieża Primeval Forest, Białowieża National Park, compartment no. 370 and 372, in Tilio-Carpinetum, a dozen of basidiocarps in groups on rich soil among nitrophilous plants; ATPOL: GC-55; 16.09.2009, 19.09.2009; leg. 
B. Gierczyk, G. Domian; det. B. Gierczyk; BGF/090916/0027, BGF/090919/0009, BGF/090919/0010.

DistRIBUTION, HABITAT AND REMARKS: Widespread but very rare species, in Europe growing on rich, often calcareous soil in mixed and deciduous forests, mainly in temperate zone (Ludwig 2001; Vellinga 2001f). Known also from Japan (Kasuya, Knudsen 2003). In Poland known from two localities - Białowieża National Park and near Opalenica (Wojewoda 2003; Bujakiewicz 2003).

\section{CONCLUSION}

The paper presents 126 localities of fungi representing the following genera: Cystolepiota, Echinoderma, Lepiota, Leucoagaricus, Leucocoprinus, Macrolepiota and Melanophyllum. The rare species known hitherto from single localities in Poland and 18 species not reported earlier from Poland are taken into regard. These species new to Poland include: Cystolepiota fumosifolia, C. moelleri, C. petasiformis, Echinoderma carini, E. pseudoasperula, Lepiota angustispora, $L$. apatelia, $L$. cingulum, $L$. cortinarius var. audreae, L. cristata var. felinoides, L. forquignonii, L. rubella, Leucoagaricus cinerascens, $L$. ionidicolor, $L$. sericifer var. sericellatus, Macrolepiota heimii, M. rhodosperma var. rhodosperma, M. venenata. They are described on the basis of micro- and macroscopic characters observed in the fruitbodies found.

Presented results should bring the inspiration for intensive field studies of above taxa in aspects of taxonomy, ecology and distribution.

Acknowledgements. The authors wish to thank Dr. Marcin Piątek for giving us access to his Lepiotaceae collection, deposited in the herbarium of the Institute of Botany, Polish Academy of Sciences, to Dr. Dariusz Karasiński for lending us a part of his private herbarium and to Mr. Marek Ciszewski, Mirosław Gryc, Krzysztof Kołodziejczyk, Bogusław Mazurek, Jacek Nowicki, Tomasz Pachlewski, Ryszard Taran, Jacek Soboń, Mirosław Wantoch-Rekowski and Piotr Zawada, participants of the mycological discussionboard (www.bioforum.pl), for collecting and sending specimens of the Lepiota and related genera. We wish also to thank Ms. Grażyna Domian, Mr. Michał Wójtowski and Maciej Zalas for joint trips and their help in field studies. Our gratitude goes also to the authorities of Bieszczady National Park and Białowieża National Park and to the Directors of City Palm House in Poznań and Polish Academy of Sciences Botanical Garden - Centre for Biological Diversity Conservation in Powsin, Warsaw for permissions to collect materials used in these studies.

\section{REFERENCES}

Adamczyk J. 2003. Macrofungi of the Ostrężnik forest reserve in the area of projected Jurassic National Park (Częstochowa Upland). Ziemia Częstochowska 30: 177-193.

Akers B. P., Sundberg W. J. 1999. Lepiotaceae of Florida, II. Lepiota s. str., Section Fuscovinaceae. Mycotaxon 70: 453-460.

de Albuquerque M. P., Pereira A. B., de Carvalho A. A. Jr. 2010. A família Agaricaceae Chevall. em trechos de Mata Atlântica da Reserva Biológica do Tinguá, Nova Iguaçu, Rio de Janeiro, Brasil: Gêneros Agaricus, Cystolepiota e Lepiota. Acta Bot. Bras. 24 (2): 497-509.

Bon M. 1993. Les Lepiotes. Lepiotaceae Roze. Generes: Cystolepiota, Melanophyllum, Echinoderma, Lepiota, Chamaemyces, Sericeomyces, Leucoagaricus, Leucocoprinus, Macrolepiota, Chlorophyllum. Flore Mycologique d'Europe 3: 1-153 (Doc. Mycologiques Memoire Hors Serie No. 3). l'Association d'Ecologie et Mycologie, Lille. 
Breitenbach J., Kränzlin F. 1995. Fungi of Switzerland. 4. Agarics. Richmond Publishing Company, Lucerna.

Bujakiewicz A. 2003. The Białowieża Forest - refuge for endangered macrofungi. Parki nar. Rez. Przyr. 22 (3): 323-346.

Bujakiewicz A. 2004. Macrofungi of the Babiogórski National park. (In:) B. Wołoszyn, A. Jaworski, J. Szwagrzyk (eds). Babiogórski Park Narodowy. Monografia Przyrodnicza, Wydawnictwo Komitetu Ochrony Przyrody PAN i Babiogórskiego Parku Narodowego, Kraków: 215-257.

Bujakiewicz A. 2010. On some agarics occurring in carr forests. Acta Mycol. 45(1): 73-89.

Bujakiewicz A. 2011. Macrofungi in the Alnetum incanae association along Jaworzyna and Skawica River valleys (Western Carpathians). Pol. Bot. J. 56(2): 267-285.

Bujakiewicz A., Kujawa A. 2010. Grzyby wielkoowocnikowe wybranych rezerwatów przyrody Puszczy Białowieskiej. Parki nar. Rez. Przyr. 29 (1): 3-26.

Bujakiewicz A., Stefaniak M. 2009. Macromycetes in forest phytocoenoses of the reserve "Las liściasty w Promnie" (Czerniejewo Forest Inspectorate). Bad. Fizjogr. Pol. Zach. B 58: 137-170.

Bujakiewicz A., Springer N. 2009. Macrofungi in carr forests of the reserve "Buki nad Jeziorem Lutomskim" (Sieraków Forest Inspectorate). Bad. Fizjogr. Pol. Zach. B 58: 171-204.

Canduso M., Lanzoni G. 1990. Lepiota s.1. Fungi Europaei. Libreria editrice Giovanna Biella, Saronno.

Flisińska Z. 2004. Grzyby Lubelszczyzny. Wielkoowocnikowe podstawczaki (Basidiomycetes). 2. Lubelskie Towarzystwo Naukowe, Lublin.

Gierczyk B., Chachuła P., Karasiński D., Kujawa A., Kujawa K., Pachlewski T., Snowarski M., Szczepkowski A., Ślusarczyk T., Wójtowski M. 2009. Macrofungi of the Polish Bieszczady Mountains. Part I. Parki nar. Rez. Przyr. 28 (3): 3-100.

Gminder A. 2003. Lepiotaceae. (In:) J. Krieglsteiner (ed.). Die Großpilze Baden-Württembergs 4: 48138. Verlag Eugen Ulmer, Stuttgart.

Halama M., Panek E. 2000. Macromycetes of various habitats of the nature reserve „Łężczok“ near Racibórz (SW Poland). Acta Mycol. 35 (2): 217-241.

Halama M., Romański M. 2010. Grzyby makroskopijne (macromycetes). (In:) L. Krzysztofiak (ed.). Śluzowce Myxomycetes, grzyby Fungi i mszaki Bryophyta Wigierskiego Parku Narodowego. Przyroda Wigierskiego Parku Narodowego. Seria naukowa. Stowarzyszenie „Człowiek i Przyroda“, Suwałki: 86-201.

Hausknecht A., Pidlich-Aigener H. 2004. Lepiotaceae (Schirmlinge) in Österreich 1. Die Gattungen Chamaemyces, Chlorophyllum, Leucoagaricus, Leucocoprinus, Macrolepiota, Melanophyllum und Sericeomyces. Z. Pilzk. 13: 1-38.

Hausknecht A., Pidlich-Aigener H. 2005. Lepiotaceae (Schirmlinge) in Österreich 2. Die Gattungen Lepiota. Z. Pilzk. 14: 41-78.

Heilmann-Clausen J. 1996a. Guirlande-Parasolhat (Lepiota cingulum) - ny for Danmark. Svampe 34: 31-33.

Heilmann-Clausen J. 1996b. Højskællet Parasolhat (Lepiota calcicola) genfundet i Møns Klinteskov. Svampe 34: 32-34.

Henrici A. 2000a. Fungal portraits. 7: Leucoagaricus ionidicolor. Field Mycol. 2 (3): 75-76.

Henrici A. 2000b. Fungal portraits. 8: Seven species of Leucoagaricus. Field Mycol. 2 (4): 111-112, 133.

Holec J. 2009. Remarks on taxonomy and ecology of Leucoagaricus ionidicolor based on a find from Central Bohemia (Czech Republic). Mycotaxon 109: 329-336.

Işiloğlu M., Watling R., Baş Sermenli H. 2010. Lepiota rubella Bres., an unusual tropical American agarics from Turkey. Turk. J. Bot. 34: 555.

Kałucka I. 2009. Macrofungi in the secondary succession on the abandoned farmland near the Białowieża old-growth forest. Monogr. Bot. 99: 1-155.

Kasuya T., Knudsen H. 2003. Two new records for Japan, Lepiota calcicola and Melanophyllum eyrei (Agaricaceae). Mycoscience 44: 327-329.

Kelderman P. H. 1994. Parasolzwammen van Zuid-Limburg Nederland. Lepiota s.1. excl. Macrolepiota. Stichting Natuurpublicaties, Limburg.

Kibby G. 2007. Fungal portraits. No. 30: Leucoagaricus nympharum. Field Mycol. 8 (2): 39-40.

Kibby G., Henrici A. 2011. Notes to British Chlorophyllum species. Field Mycol. 12 (3): 8-93.

Kirk P.M., Cannon P.F., Minter D.W., Stalpers J.A. 2008. Ainsworth \& Bisby's Dictionary of the Fungi. $10^{\text {th }}$ Edition. CAB International.

Knudsen H. 2005. Nogle nye danske parasolhatte. Svampe 51: 50-56. 
Kosakyan A., Didukh M., Ur Y., Wasser S. P., Nevo E. 2008a. Lepiota (Agaricaceae, Basidiomycota) species diversity in Israel. Mycotaxon 105: 355-377.

Kosakyan A., Ur Y., Wasser S. P., Nevo E. 2008b. Rare and noteworthy lepiotaceous species (Basidiomycota, Agaricales, Agaricaceae) from Israel. Mycotaxon 103: 59-74.

Kujawa A. 2009. Macrofungi of wooded patches in the agricultural landscape. I. Species diversity. Acta Mycol. 44 (1): 49-75.

Kujawa A. 2011. Grzyby makroskopijne Polski w literaturze mikologicznej. (In:) M. Snowarski (ed.). Atlas grzybów Polski (http://www.grzyby.pl/grzyby-makroskopijne-Polski-w-literaturze-mikologicznej. htm). Version December 2011. Accessed 12.2011.

Kujawa A., Gierczyk B. 2007. Register of protected and endangered fungi species in Poland. Part II. A list of species recorded in 2006 year. Przegląd Przyrodniczy 18 (3/4): 3-70.

Kujawa A., Gierczyk B. in press. Register of protected and endangered fungi species in Poland. Part IV. A list of species recorded in 2009 year. Przegląd Przyrodniczy.

Kumar T. K. A., Manimohan P. 2009b. The genus Lepiota (Agaricales, Basidiomycota) in Kerala State, India. Mycotaxon 107: 105-138.

Kumar T. K. A., Manimohan P. 2009a. The genus Cystolepiota (Agaricales, Basidiomycota) in Kerala State, India. Mycotaxon 107: 277-284.

Lange C. 2008a. Chlorophyllum Massee. (In:) H. Knudsen, J. Vesterholt (eds). Funga Nordica. Agaricoid, boletoid and cyphelloid genera. Nordsvamp, Copenhagen: 531-532.

Lange C. 2008b. Cystolepiota Singer. (In:) H. Knudsen, J. Vesterholt (eds). Funga Nordica. Agaricoid, boletoid and cyphelloid genera. Nordsvamp, Copenhagen: 533-535.

Lange C. 2008c. Echinoderma (Bon) Bon. (In:) H. Knudsen, J. Vesterholt (eds). Funga Nordica. Agaricoid, boletoid and cyphelloid genera. Nordsvamp, Copenhagen: 535-538.

Lange C. 2008d. Lepiota (Pers.) Gray. (In:) H. Knudsen, J. Vesterholt (eds). Funga Nordica. Agaricoid, boletoid and cyphelloid genera. Nordsvamp, Copenhagen: 538-548.

Lange C. 2008e. Leucoagaricus Singer. (In:) H. Knudsen, J. Vesterholt (eds). Funga Nordica. Agaricoid, boletoid and cyphelloid genera. Nordsvamp, Copenhagen: 548-553.

Lange C. 2008f. Leucocoprinus Pat. (In:) H. Knudsen, J. Vesterholt (eds). Funga Nordica. Agaricoid, boletoid and cyphelloid genera. Nordsvamp, Copenhagen: 553-554.

Lange C. 2008g. Macrolepiota (Pers.) Gray. (In:) H. Knudsen, J. Vesterholt (eds). Funga Nordica. Agaricoid, boletoid and cyphelloid genera. Nordsvamp, Copenhagen: 554-557.

Lange C. 2008h. Melanophyllum Velen. (In:) H. Knudsen, J. Vesterholt (eds). Funga Nordica. Agaricoid, boletoid and cyphelloid genera. Nordsvamp, Copenhagen: 557.

Lange C., Vellinga E. C. 2004. Rabarber-Parasolhat holder flyttedag - molekylærgenetiske studier omkring slægten Macrolepiota. Svampe 50: 23-42.

Legon N. W., Henrici A., Roberts P. J., Spooner B. M., Watling R. 2005. Checklist of the British \& Irish Basidiomycota. Royal Botanic Gardens, Kew.

Lisiewska M. 2004. Zmiany w składzie gatunkowym i ilościowości macromycetes Arboretum Kórnickiego po 25 latach. Bad. Fizjogr. Pol. Zach. B 53: 7-27.

Lisiewska M. 2006. Endangered macrofungi of selected nature reserves in Wielkopolska. Acta Mycol. 41 (2): 241-252.

Ludwig E. 2000. Pilzkompendium. Band 1. Abbildungen. Die kleiner Gattungen der Macromyzeten mit lamelligem Hymenophor aus den Ordnungen Agaricales, Boletales und Polyporales. IHW-Verlag, Eching.

Ludwig E. 2001. Pilzkompendium. Band 1. Beschreibungen. Die kleiner Gattungen der Macromyzeten mit lamelligem Hymenophor aus den Ordnungen Agaricales, Boletales und Polyporales. IHW-Verlag, Eching.

Ławrynowicz M. 2001. Grzyby południowo-wschodniej części Borów Tucholskich. (In:) J. Pająkowski (ed.). Krajobrazy Ziemi Świeckiej. Towarzystwo Przyjaciół Ziemi Świeckiej, Świecie: 181-189.

Ławrynowicz M., Dziedziński T., Szkodzik J. 2002. Macrofungi of Aceri-Tilietum and Tilio-Carpinetum in the "Dolina Rzeki Brdy" nature reserve in the Bory Tucholskie (NW Poland). Acta Mycol. 37 (1/2): 63-76.

Luszczyński J. 2007. Diversity of Basidiomycetes in various ecosystems of the Góry Świętokrzyskie Mts. Monogr. Bot. 97: 5-218.

Łuszczyński J. 2008. Basidiomycetes of the Góry Świętokrzyskie Mts. A checklist. Wydawnictwo Uniwersytetu Humanistyczno-Przyrodniczego Jana Kochanowskiego, Kielce. 
Łuszczyński J., Łuszczyńska B., Sikora A., Jaworska J. 2011. New and rare species of agaricoid fungi in thermophilic grasslands of the Wyżyna Małopolska upland. (In:) M. Ławrynowicz, M. RuszkiewiczMichalska, I. Kałucka (eds). Traditional use and protection of fungi in Poland: a contribution to the European cultural heritage. Book of abstracts. Wydawnictwo Uniwersytetu Łódzkiego, Łódź: 77.

Malysheva E. F. 2005. Lepiota pseudoasperula (Agaricaceae), new to Russia. Mycotaxon 91: 365-368.

Migliozzi V., Bizzi A. 1994. Lepiotacee interessanti o rare. $1^{\circ}$ contributo. Lepiota alba var. angustispora var. nova, L. alba ad ochraceodiscam, L. clypeolarioides fo. e L. forquignonii. Micologia Italiana 23 (3): 29-48.

Mirek Z., Piekoś-Mirkowa H., Zając A., Zając M. 2002. Flowering plants and pteridophytes of Poland. A. Checklist. (In:) Z. Mirek (ed.). Biodiversity of Poland 1. W. Szafer Institute of Botany, Polish Academy of Sciences, Kraków.

Narkiewicz C. 2011. Sprawozdanie z XXI wystawy świeżych grzybów w Jeleniej Górze. Przyr. Sudetów 14: 223-229.

Nita J., Bujakiewicz A. 2007. Łęgi i olsy ostoją rzadkich i zagrożonych grzybów wielkoowocnikowych. Studia i Materiały Centrum Edukacji Przyrodniczo-Leśnej. 9 (2/3): 519-529.

Pearson B. D. 2007. Lepiota on the outwood trail. Field Mycol. 8 (2): 66-69.

Rald E., Heilmann-Clausen J., Lange C. 1992. 1991 - et godt år for parasolhatte. Svampe 26: 33-40.

Rald E., Heilmann-Clausen J. 1993. Danske parasolhatte af slægten Lepiota - sektionerne Lilaeeae og Fuscovinaceae. Svampe 28: 47-54.

Rother M. S., da Silveira R. M. B. 2009. Leucocoprinus Pat. (Agaricaceae, Basidiomycota) no Parque Estadual de Itapuã, Viamão, RS, Brasil. Acta Bot. Bras. 23 (3): 720-728.

Stasińska M. 2003. Różnorodność grzybów (macromycetes) w warunkach naturalnej sukcesji muraw stepowych. (In:) S. M. Rogalska, J. Domagała (eds). Człowiek i środowisko przyrodnicze Pomorza Zachodniego. Uniwersytet Szczeciński, Szczecin: 31-34.

Sysouphanthong P., Hyde K. D., Chukeatirote E., Bahkali A. H., Vellinga E. C. 2011. Lepiota (Agaricales) in northern Thailand - 1. L. section Stenosporae. Mycotaxon 117: 53-85.

Szczepkowski A., Kujawa A., Karasiński D., Gierczyk B. 2008. Fungi gathered for the XIV Fungi Exposition of the Białowieża Forest. Parki nar. Rez. Przyr. 27 (4): 115-133.

Ślusarczyk T. 2009. Rare and protected species of large-fructification fungi found in "Owczary" protected area. Przegląd Przyrodniczy 20 (1/2): 11-33.

Škubla P. 2003. Mycoflora Slovaca. Bratislava.

Tofts R. 2002. The British species of Lepiota. 1: Section Stenosporae. Field Mycol. 3 (4): 124-136.

Vellinga E. C. 2000. Notes on Lepiota and Leucoagaricus. Type studies on Lepiota magnispora, Lepiota barssii and Agaricus americanus. Mycotaxon 76: 429-438.

Vellinga E. C. 2001a. Macrolepiota Sing. (In:) M. E. Noordeloos, T. W. Kuyper, E. C. Vellinga (eds). Flora Agaricina Neerlandica. Critical monographs on families of agarics and boleti occurring in the Netherlands. 5: 64-73. A.A. Balkema Publishers, Lisse.

Vellinga E. C. 2001b. Leucocoprinus Pat. (In:) M. E. Noordeloos, T. W. Kuyper, E. C. Vellinga (eds). Flora Agaricina Neerlandica. Critical monographs on families of agarics and boleti occurring in the Netherlands 5: 76-84. A.A. Balkema Publishers, Lisse.

Vellinga E. C. 2001c. Leucoagaricus (Locq. ex) Sing. (In:) M. E. Noordeloos, T. W. Kuyper, E. C. Vellinga (eds). Flora Agaricina Neerlandica. Critical monographs on families of agarics and boleti occurring in the Netherlands 5: 85-108. A.A. Balkema Publishers, Lisse.

Vellinga E. C. 2001d. Lepiota (Pers. : Fr.) S.F. Gray. (In:) M. E. Noordeloos, T. W. Kuyper, E. C. Vellinga (eds). Flora Agaricina Neerlandica. Critical monographs on families of agarics and boleti occurring in the Netherlands 5: 109-151. A.A. Balkema Publishers, Lisse.

Vellinga E. C. 2001e. Cystolepiota Sing. (In:) M. E. Noordeloos, T. W. Kuyper, E. C. Vellinga (eds). Flora Agaricina Neerlandica. Critical monographs on families of agarics and boleti occurring in the Netherlands 5: 154-160. A.A. Balkema Publishers, Lisse.

Vellinga E. C. 2001f. Melanophyllum Velen. (In:) M. E. Noordeloos, T. W. Kuyper, E. C. Vellinga (eds). Flora Agaricina Neerlandica. Critical monograps on families of agarics and boleti occurring in the Netherlands. 5: 161-162. A.A. Balkema Publishers, Lisse.

Vellinga E. C. 2001g. Studies of Lepiota III. Some species from California, U.S.A. Mycotaxon 80: $285-295$.

Vellinga E. C. 2003a. Chlorophyllum and Macrolepiota (Agaricaceae) in Australia. Austral. Sys. Bot. 16: 361-370. 
Vellinga E. C. 2003b. Type studies in Agaricaceae - Chlorophyllum rachodes and allies. Mycotaxon 85: 259-270.

Vellinga E. C. 2006. Lepiotaceous fungi in California, U.S.A. - 4. Type studies of Lepiota fumosifolia and L. petasiformis. Mycotaxon 98: 225-232.

Vellinga E. C. 2007. Key to the Cystolepiota species in western North America. (http://nature.berkeley. edu/brunslab/ev/vellinga_2007_cystolep_key.pdf)

Vellinga E.C. 2008. Chlorophyllum. (http://nature.berkeley.edu/brunslab/ev/CHLOROPHYLLUM.pdf)

Vellinga E. C. 2010. Lepiota in California: species with a hymeniform pileus covering. Mycologia 102 (3): 664-674.

Vellinga E. C., Franco-Molano A. E., Bas C. 1998. Studies in Lepiota II. - Lepiota rubella. Sydowia 50 (2): 272-277.

Vellinga E., Huijser H. 1998a. Notes on Cystolepiota. Sections Cystolepiota and Pulverulenta. Persoonia 16 (4): 513-526.

Vellinga E., Huijser H. 1998b. Studies in Lepiota, I. Species with a hymeniform pileus covering. Belg. J. Bot. 131 (2): 191-211.

Vizzini A., Contu A., Ghignone S., Vellinga E. 2011. A new volvate Macrolepiota (Agaricomycetes, Agaricales) from Italy, with observations on the M. procera complex. Mycotaxon 117: 149-164.

Wang H-C. 2004. Lepiota cortinarius, a species new to China. Mycosystema 23 (3): 439-440.

Wasser S. P. 1985. Agarikowe griby CCCP. Naukowa Dumka, Kijew.

Wojewoda W. 2003. Checklist of Polish larger Basidiomycetes. (In:) Z. Mirek (ed.). Biodiversity of Poland 7. W. Szafer Institute of Botany, Polish Academy of Sciences, Kraków.

Wojewoda W. 2005. Grzyby Krzemionek Podgórskich. (In:) M. Szczepańska, E. Pilecka (eds). Geologiczno-przyrodnicze rozpoznanie terenów Krzemionek Podgórskich dla potrzeb ochrony ich wartości naukowo-dydaktycznych i ekologicznych.Wydawnictwo Instytutu Gospodarki Surowcami Mineralnymi i Energią PAN, Kraków: 76-86.

Wojewoda W. 2008. Grzyby wielkoowocnikowe Ojcowskiego Parku Narodowego. (In:) A. Klasa, J. Partyka (eds). Monografia Ojcowskiego Parku Narodowego. Ojcowski Park Narodowy, Muzeum im. Prof. Władysława Szafera, Ojców: 317-334.

Wojewoda W., Karasiński D. 2010. Invasive macrofungi (Ascomycota and Basidiomycota) in Poland. (In:) Z. Mirek (ed.). Biological Invasions in Poland 1: 7-21. W. Szafer Institute of Botany, Polish Academy of Sciences, Kraków.

Wojewoda W., Ławrynowicz M. 2006. Red list of the macrofungi in Poland. (In:) Z. Mirek, K. Zarzycki, W. Wojewoda, Z. Szeląg (eds). Red list of plants and fungi in Poland: 53-70. W. Szafer Institute of Botany, Polish Academy of Sciences, Kraków.

Zelený L. 2006. Taxonomic literature on the genus Lepiota s. 1. in the Czech Republic. Czech Mycol. 58 (3/4): 225-265.

\section{Rzadkie gatunki z rodzaju Lepiota i rodzajów pokrewnych}

\section{Streszczenie}

W pracy przedstawiono 126 stanowisk grzybów należących do rodzajów Cystolepiota, Echinodema, Lepiota, Leucoagaricus, Leucocoprinus, Macrolepiota i Melanophyllum. Zaprezentowano gatunki rzadkie, znane z nielicznych stanowisk w Polsce oraz 18 taksonów nowych dla tego terenu (Cystolepiota fumosifolia, C. moelleri, C. petasiformis, Echinoderma carini, E. pseudoasperula, Lepiota angustispora, L. apatelia, L. cingulum, L. cortinarius var. audreae, L. cristata var. felinoides, L. forquignonii, L. rubella, Leucoagaricus cinerascens, L. ionidicolor, L. sericifer var. sericellatus, Macrolepiota heimii, M. rhodosperma var. rhodosperma, M. venenata). Gatunki nie notowane wcześniej z obszaru Polski opisano w oparciu o cechy znalezionych okazów. 